\title{
Review
}

\section{LRRK2: Cause, Risk, and Mechanism}

\author{
Coro Paisán-Ruiz ${ }^{\mathrm{a}, \mathrm{b}}$, Patrick A. Lewis ${ }^{\mathrm{c}, \mathrm{d}}$ and Andrew B. Singleton ${ }^{\mathrm{e}, *}$ \\ ${ }^{a}$ Department of Neurology, Psychiatry, and Genetics and Genomic Sciences, Icahn School of Medicine at Mount \\ Sinai, One Gustave L. Levy Place, NY, USA \\ ${ }^{\mathrm{b}}$ Friedman Brain and Mindich Child Health and Development Institutes, Icahn School of Medicine at Mount Sinai, \\ One Gustave L. Levy Place, NY, USA \\ ${ }^{\mathrm{c}}$ Department of Molecular Neuroscience, UCL Institute of Neurology, University College London, Queen Square, \\ London, UK \\ ${ }^{\mathrm{d}}$ School of Pharmacy, University of Reading, Whiteknights, Reading, UK \\ ${ }^{\mathrm{e}}$ Laboratory of Neurogenetics, National Institute on Aging Intramural Research Program, Bethesda, MD, USA
}

\begin{abstract}
In 2004 it was first shown that mutations in LRRK2 can cause Parkinson's disease. This initial discovery was quickly followed by the observation that a single particular mutation is a relatively common cause of Parkinson's disease across varied populations. Further genetic investigation has revealed a variety of genetic ties to Parkinson's disease across this gene. These include common alleles with quite broad effects on risk, likely through both alterations at the protein sequence level, and in the context of expression. A great deal of functional characterization of LRRK2 and disease-causing mutations in this protein has occurred over the last 9 years, and considerable progress has been made. Particular attention has been paid to the kinase activity of LRRK2 as a therapeutic target, and while it is no means certain that this is viable target it is likely that this hypothesis will be tested in clinical trials sooner rather than later. We believe that the future goals for LRRK2 research are, while challenging, relatively clear and that the next 10 years of research promises to be perhaps more exciting than the last.
\end{abstract}

Keywords: LRRK2, associated phenotype, disease risk, biology, future challenges, Parkinson's disease, parkinsonism, genetics

\section{INTRODUCTION}

The identification of $L R R K 2$ mutations as a cause of PD in 2004 had an instant, significant, and lasting impact on our understanding of Parkinson's disease (PD) $[1,2]$. This work provided surprising insight into the genetic basis of this disease, revealing that mutations underlie a substantive number of PD cases throughout the World. The protein product of this gene, a kinase, also provided hope, as it was immediately suggested that this would prove to be a druggable target for treating both genetic and idiopathic forms of PD. In this article we will review and discuss the significant progress that has been made in understanding

*Correspondence to: Andrew Singleton, Molecular Genetics Section and Laboratory of Neurogenetics, NIA, NIH, 35 Convent Drive, Bethesda, MD 20892, USA. Tel.: +1 301451 6079; Fax: +1 301451 5466; E-mail: Singleta@mail.nih.gov. the role of $L R R K 2$ in PD, both from the perspective of genetics, and through understanding the etiology and pathogenesis of this disorder.

\section{PARKINSON'S DISEASE-ASSOCIATED LRRK2 MUTATIONS}

Mutations in LRRK2 (NM_198578.3) are the most common genetic cause of late-onset Parkinson's disease (PD) identified to date $[1,2]$. LRRK2 consists of 51 coding exons and encodes a large 2,527amino acid protein called dardarin, which consists of several leucine-rich repeats (LRRs), a Ras-like GTPase domain (ROC) along with its C-terminal domain (COR), a kinase domain, as well as a WD40 motif. Although over 100 LRRK2 mutations have already been reported [3], only a few have been 


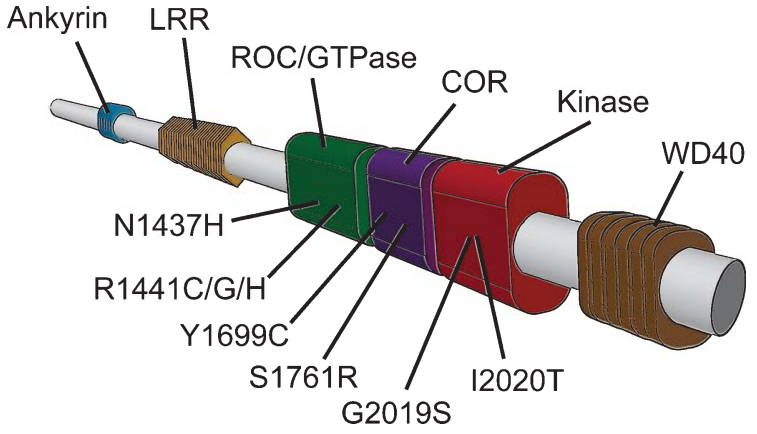

Fig. 1. LRRK2 ideogram showing functional domains and penetrant mutations.

proven to cause PD. These include the p.N1437H, p.R1441C/G/H, p.Y1699C, p.S1761R, p.G2019S, p.I2012T, and p.I2020T mutations [4-7] (Fig. 1). Interestingly, all established pathogenic mutations are clustered among the three domains that form the enzymatic core of dardarin and are associated with variable degrees of population-specificity [7].

The most frequent LRRK2 mutation, p.G2019S, while barely present in Asia $(<0.1 \%)$, is responsible for up to $10 \%$ of apparently sporadic PD and up to $42 \%$ of familial PD [5, 8]; although this mutation has a worldwide distribution, it is present with a higher frequency in Portuguese (16\%), Ashkenazi Jewish (28\%), and North African Arab (42\%) populations [9-11]. Similarly, within the Basque population the $L R R K 2$ p.R $1441 \mathrm{G}$ mutation presents at a frequency of $2.5 \%$ and $46 \%$ in apparently sporadic and familial $\mathrm{PD}$, respectively but is hardly present in other European populations, including other regions of Spain, or North and South America [12-15]. In contrast, the p.R1441C mutation represents the second most common LRRK2 mutation identified in Europe, being the major genetic cause of PD among Belgian PD patients, likely due to a founder effect [16]. Although the p.R1441G/C mutations have not been reported among Asian PD patients, the p.R1441H mutation has been found in Asia, Europe, and North America [17, 18]. Only four families have been described with the p.I2020T mutation, notably however, this includes the Sagamihara kindred, the first reported family with PD linked to the LRRK2 locus [19]. Lastly the p.Y1699C mutation, sitting within the COR domain, has been reported in several families of British (1), German-Canadian (1), and Korean (1) origin [1, 2, 20].

While it is likely that at least some of the other reported mutations in LRRK2 are pathogenic, in most instances the segregation or association data are insufficient to prove pathogenicity. Consequently, the majority of research conducted in understanding the clinical, pathological, and biochemical consequences of $L R R K 2$ mutation is limited to the mutations described above.

\section{LRRK2-associated phenotype}

Given the high frequency of the p.G2019S mutation, the majority of $L R R K 2$ disease related clinical data are associated with this mutation. Most reports agree that the phenotypic features associated with $L R R K 2$ disease, characterized by unilateral tremor as initial symptom, good response to levodopa therapy, and slow, benign disease progression, closely resemble those seen in idiopathic Parkinson's disease (IPD). Tremor is the most commonly recognized initial symptom [7,21]; indeed $L R R K 2$-associated disease has been categorized by a large collaborative study as an asymmetrical tremor-predominant parkinsonism with bradykinesia and rigidity [22]. It has also been suggested that $L R R K 2$ associated disease may be marginally more benign than IPD. LRRK2 mutation carriers usually present with lower risk of cognitive decline [22, 23] than IPD patients, and in general cognitive decline and psychiatric features are rarely reported in symptomatic LRRK2 mutation carriers [22, 24]. Conversely a high frequency of depression, anxiety, and irritability, and a trend toward a greater risk of premorbid mood disorders have recently been reported in symptomatic $L R R K 2$ mutation carriers by two independent studies $[25,26]$. Although dystonia and levodopa-induced dyskinesias (LID) seem to be more frequent in p.G2019S carriers than IPD, dystonia appears to be triggered by complications of medical or surgical treatments and the differences in LID did not reach statistical significances [22, 27].

There has been much discussion over the pentrance of $L R R K 2$ mutations, with estimates ranging from $30 \%$ to $80 \%$. Initial estimates were likely skewed by the inherent ascertainment bias of family based studies, and by rather small numbers and age ranges for cohort based work. A more reasonable model has evolved over several years, being one that takes into account age with penetrance modeled in a large group of cases and controls from around the World. This shows that the penetrance of $L R R K 2$ mutations is clearly age dependent, increasing from $17 \%$ at age 50 to $85 \%$ at age 70 years [28]; notably some p.G2019S mutation carriers do not manifest disease even in their eighties or later [29].

Given the large number of asymptomatic p.G2019S mutation carriers, numerous reports are now focused on these healthy carriers in an effort to identify early 
preclinical biomarkers of PD. Within this context, lower cognitive performances have been reported in non-manifesting p.G2019S mutation carriers when compared to healthy non-carriers, suggesting cognitive impairment, though not commonly seen in symptomatic carriers, as a preclinical non-motor symptom of PD [30]. A higher frequency of postural and action tremor as well as gait alterations have also been reported in non-manifesting carriers [21,31].

Olfactory dysfunction (hyposmia), a wellestablished non-motor feature of IPD that may precede disease onset and is present in 70-90\% of patients with PD, has been widely studied in p.G2019S mutation carriers [32, 33]. Most reports agree that symptomatic p.G2019S mutation carriers also manifest olfactory dysfunction, although this is less frequent than in IPD [34, 35]. Similar findings have been reported in p.R1441G mutation carriers [36]. On the other hand, healthy mutation carriers exhibited similar levels of hyposmia to healthy noncarriers, including non-manifesting relatives, raising the possibility that the occurrence of this non-motor symptom of PD may be independent of the LRRK2 mutation, or quite a late event in the disease process $[21,37]$.

In short, the LRRK2-associated phenotypic spectrum largely resembles the idiopathic disease and although some efforts have been carried out to establish pre-motor biomarkers for PD in LRRK2 patients, more work remains to be done toward this end.

\section{LRRK2-associated neuropathology}

Postmortem data available for about 40 LRRK2 mutation carriers has revealed that the LRRK2associated neuropathology is fairly heterogeneous. Although it is mainly characterized by the loss of dopaminergic neurons and the presence of Lewy bodies (LBs) and Lewy neurites (LNs), these are not present in all cases and the same mutation can cause quite diverse neuropathology [38, 39]. Despite this, the p.G2019S mutation is often associated with Lewy body pathology and neuronal loss in the substantia nigra (SN), tau pathology without LBs or LNs, and neuronal loss restricted to the $\mathrm{SN}$, indicating that LRRK2 mutation does not always manifest as synucleinopathy or LB disease [40]. Similar findings have been reported for the p.I2020T mutation, where five out of six mutation carriers exclusively showed tau pathology while tau-positive lesions, restricted to the brainstem along with alpha-synuclein deposits, were unique to one patient [41]; the p.Y1699C mutation, who carriers showed nigral neuronal loss and gliosis with either cortical and brainstem LBs or ubiquitinpositive cytoplasmic and nuclear inclusions [42, 43]; and the p.R1441C mutation, in which available data from four patients also revealed variable synuclein and tau pathology: LBs and LNs were detected in two cases (one with brainstem LB disease and one with diffuse LB disease), neurofibrillary tangles (NFT) without either LBs or LNs were identified in a third patient, while neither the presence of LBs nor NFT were found in the fourth patient [44]. The only case examined with the p.R1441G mutation showed loss of dopaminergic neurons in SN without alpha-synuclein inclusions [45]. More recently, the p.N1437H mutation has also been associated with almost a high degree of dopaminergic cell loss in the SN pars compacta, brainstem, and cortex but sparse alpha-synuclein pathology, and pronounced ubiquitin-positive pathology in the brainstem, temporolimbic regions, and neocortex [46].

In conclusion, LRRK2-associated pathology, although mainly characterized by pure nigral neurodegeneration, is strikingly heterogeneous and can additionally present as tau-, alpha-synuclein-, TDP-43(one case), or ubiquitin-positive pathologies [39].

\section{LRRK2 mutation modifiers}

The reduced penetrance and the variability in the age at onset (AAO) and neuropathology identified in LRRK2 mutation carriers suggests that LRRK2associated PD is probably modulated by a combination of both environmental and genetic factors. Considering the neuropathological findings in LRRK2 mutation carriers, one might speculate that both $S N C A$ and $M A P T$ genes, which in turn are associated with the risk of PD [47], may also affect the LRRK2-related phenotypic expression. Indeed, two different studies have recently reported that two different MAPT alleles (rs2435207 and rs11079727) substantially affect the age at onset of motor symptoms in LRRK2 mutation carriers. In both studies heterozygous carriers of the minor alleles (rs2435207-A and rs11079727-A) developed the parkinsonian symptoms approximately seven years later [48, 49]. Additionally, two SNCA polymorphisms (rs356165 and rs356219) have been identified as modifiers of the age at onset in both IPD and LRRK2-related PD by two independent studies, respectively. One study demonstrated that both heterozygous and homozygous IPD carriers of the major allele, rs356165-G, presented with earlier AAO than homozygous carriers of the minor allele (rs356165-A) with approximately 3 years of difference [50]. A second study showed that 
PD patients carrying the p.G2019S mutation also presented with earlier AAO when jointly carried the $S N C A$ rs356219-G allele; in this study patients developed the parkinsonian symptoms approximately 9 years earlier than carriers of the homozygous rs356219-A allele [51].

Although these results were carried out in quite small cohorts they provide the first evidence supporting the notion that varied presentation of $L R R K 2$ disease may arise from a combination of multifactorial events. Further research is required to support these results and extend the search for modulating environmental and genetic factors that may affect the clinical presentation of $L R R K 2$ disease.

\section{BEYOND DISEASE CAUSING MUTATIONS: LRRK2 AND RISK}

As discussed above, the first PD linked variants identified in $L R R K 2$ were essentially disease causing mutations, each being relatively rare in the general population. What has become apparent over the last 9 years is that the genetic contribution of this locus to PD is not merely limited to disease causing mutations, but also includes variants that impart varying degrees of risk for this disease.

\section{Common protein-coding LRRK2 variants as risk factors for disease}

In the wake of the original LRRK2 mutation reports, a large number of screening efforts were performed both to define PD linked variants and to characterize the genetic variability in and around $L R R K 2$. As described above, this work produced a large list of variants linked to disease, the majority only tenuously. Initial efforts failed to create a convincing argument that common risk variants existed at this locus [52-54], however, after several years of effort the relationship between common variants at this locus and risk for disease has become clearer.

As a part of a mutation screening effort, the LRRK2 variant p.G2385R was identified as a possible cause of $\mathrm{PD}$ in a father-daughter pair of patients originating from Taiwan [55]. Less than a year after this finding, it became apparent that this alteration was unlikely to cause PD, but may play a more interesting role in disease. In 2006 Vincenzo Bonifati led a study testing $L R R K 2$ variants in a case control population from Taiwan. This groups data showed p.G2385R to be relatively common in the control population, being carried by about 1 in every 20 people free from disease, certainly too common to be considered a mutation, but that this variant was twice as common in PD patients [56]. This work, which was performed in a series of $\sim 600$ cases and $\sim 375$ controls, therefore suggested that the p.G2385R increases risk for disease by about 2 fold; while this was only a relatively modest effect it has certainly been borne out by subsequent studies. Immediately after this initial result 2 studies confirmed this association both in Taiwanese and ethnic Chinese patients from Singapore $[57,58]$. Since then a large number of reports have investigated this polymorphism and confirmed an association in varied Asian populations including Taiwanese, Singaporean Malays, Han Chinese, Hong Kong Chinese, Korean, and Japanese [59-68]. An excellent and frequently updated synopsis of these findings is maintained at the online PDgene repository (http://www.pdgene.org/meta.asp?geneID=13) [69], also adapted here (Fig. 2). While the magnitude and effect of p.G2385R has been borne out consistently in Asian populations, this alteration has essentially been too rare in other populations to observe any disease-linked effect.

A second coding variant, p.R1628P has been examined extensively across Asian populations following an initial report suggesting it conferred risk of a similar magnitude to p.G2385R [70]. In this original work Ross and colleagues identified p.R1628P as a risk factor in ethnic Chinese populations from Singapore and Taiwan, conferring an increased risk of 1.84 fold $(95$ CI 1.2-2.8). Similar to p.G2385R, the p.R1628P variant exhibits a low allele frequency, being present in $\sim 3 \%$ and $\sim 6 \%$ of ethnic Chinese controls and cases respectively. p.R1628P was described as rare or absent in Indian, and Japanese subjects. Examination of this variant in a series of Malay patients showed no association with disease, however, this likely reflects the insufficient power of this small series to detect an effect of the expected magnitude rather than a genuine lack of effect [70, 71]. Replication of the association between p.R1628P and disease has been largely consistent and has been performed in Han Chinese, and Korean patients [65, 72-75] (Fig. 2). Further an association with PD was identified in the Thai population, and given the high observed frequency of the variant allele in this population, the authors argued that this variant may have emerged from a Thai founder [76].

One of the most comprehensive studies into the role of LRRK2 variants in disease was centered on genotyping of 121 exonic variants within the gene across a series of $\sim 7000$ Caucasian patients, $\sim 5600$ Caucasian controls, $\sim 1400$ Asian patients, and $\sim 1000$ Asian 
P.G2385R

Asian Studies
Asian Excluding Initial
Study Specific Odds Ratios
Lin, 2010
Miyake, 2010
Pulkes, 2010
Tan, 2010
Kim, 2009
Zabetian, 2009
Choi, 2008
Chan, 2008
Li, 2007
Tan, 2007
Funayama, 2007
Fung, 2006
Tan, 2006
Di Fonzo, 2006

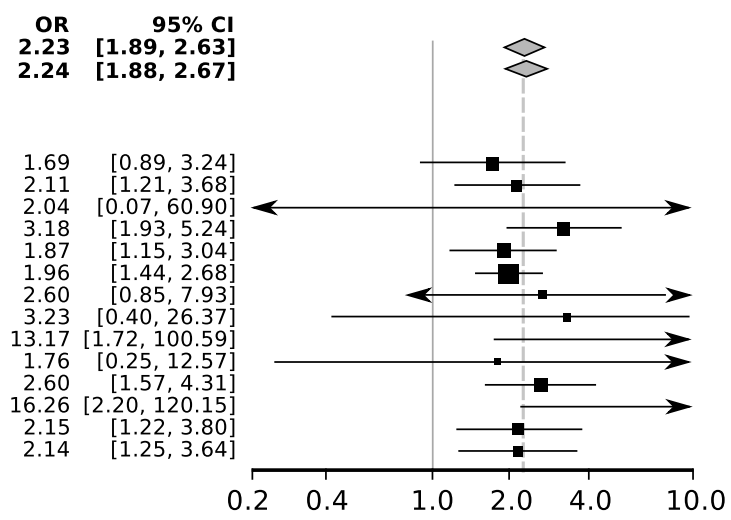

\section{p.R1628P}

\section{Asian Studies} Asian Excluding Initial

OR
$2.13 \quad[1.67,2.73]$ $\begin{array}{ll}2.13 & {[1.67,2.73]} \\ 2.30 & {[1.72,3.07]}\end{array}$

Study Specific Odds Ratios Pulkes, 2010

Tan, 2010

Tan, 2010

Tan, 2010

Kim, 2009

Lu, 2008

Tan, 2008

Ross, 2008

Ross, 2008

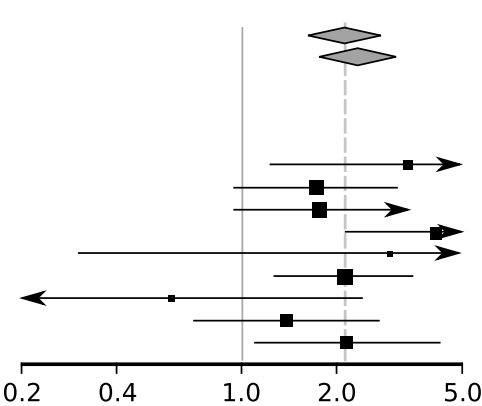

Fig. 2. Forest plot showing risk associated with the p.G2385R Lrrk2 variant. Modified from PDGene (http://www.pdgene.org/meta.asp? geneID=13) [69] to show only studies performed in Asian populations. Data abstracted in January 2013.

controls [17]. The authors gathered a series of rare and common variants from published studies, public databases, and their own sequencing data, then tested association for these across these large series of cases and controls. This work supported a role for p.G2385R as a risk variant in the Asian population, although not p.R1628P. In the Caucasian series the authors noted association between p.M1646T and disease (OR 1.43, 95\% CI 1.15-1.78). This variant had been tested previously as a putative risk allele for PD with no obvious association, however, each of these small studies were relatively unlikely to yield positive results for a variant conferring such a modest effect size [77-79]. In the same study the authors also identified an association between protection against disease and a 3 variant haplotype p.N551K-p.R1398H-p.K1423K, the data in this study being consistent with a general protective effect in both Caucasian and Asian series [17]. These three variants exist in strong linkage disequilibrium, so it is not yet clear which of the three (or which combination) is the biological effector.
Lastly, in the work by Ross and colleagues p.A419V was posited as a potential risk variant in the Asian population [17]. While replication has been attempted, thus far the results remain inconclusive [80-83].

\section{Common non-coding LRRK2 variants as risk factors for disease}

The majority of replicated genetic association loci for complex traits are not linked to obvious protein coding alterations and it is believed that these are likely to exert a biological effect through mediating expression and splicing [84]. It would appear feasible then that non-coding risk variants exist at the $L R R K 2$ locus in addition to protein coding risk variants. While initial efforts to show that this may be true were largely unsuccessful there has been increasingly compelling evidence of an association at $L R R K 2$ with disease from genome wide association studies. The first suggestion of this effect was seen by two coordinated studies in 2009 performed in Asian and Caucasian cohorts 
$[47,85]$. This association in both the Caucasian and Asian data was most prominent 5' to the proteincoding region of LRRK2 and was independent of the well known p.G2019S mutation. The association has been replicated in subsequent well-powered association studies $[86,87]$. These studies have shown quite modest effects of risk alleles at $L R R K 2$ with odds ratios in the range of $\sim 1.2-1.3$, consistent with that seen at most other risk loci identified by GWA.

\section{Future work on LRRK2 and disease risk}

As discussed there is good evidence that variability in and around $L R R K 2$ contributes to risk for PD and that $L R R K 2$ accounts for a greater proportion of the genetic architecture of PD than previously appreciated. The website PDGene goes some way toward identifying $L R R K 2$ variants that confer risk by compiling existing data; however, there is a need to assimilate current genetic data on $L R R K 2$ variants and perform more extensive data generation in an effort to unequivocally define alleles associated with risk for, and plausibly protection against, disease. Given the large size of this gene, direct genotyping, sequencing, and replication would have the benefit of providing information on linkage disequilibrium of variants, and establishing independency of effects. This type of work is not only important because it clarifies the role this gene product plays in disease, but also because it is key that scientists trying to understand the functional basis of lrrk2 in disease know which are truly associated variants, and which are not. From a genetic perspective this must be one of our research priorities in understanding LRRK2 and disease.

There are a few as yet answered questions regarding the association of common non-coding risk variants near $L R R K 2$ and disease. Firstly, are there several noncoding risk variants at $L R R K 2$; secondly, what is (are) the biologically relevant variant(s); and thirdly, what is the biological consequence of this variant. It is likely that fine mapping and resequencing efforts may go some way toward answering the first two questions. It is reasonable to assume that non-coding variants exert their effect through mediating expression of proximal transcripts, and good evidence exists to support this idea [88]; to date there is not compelling evidence of such an association for the LRRK2 risk alleles. There are many reasons why this may be, the change in expression may be too subtle to detect with current methods, it may be only apparent under certain states or in certain cell types, or it may effect splicing or UTR usage rather than the overall level of transcript.
It is likely that the increasing availability of reference data sets for genotype-expression-epigenetic correlation and improved methods for transcript profiling may help in dissecting out the relationship between risk alleles and biological consequence.

A clear trend in PD genetics is the existence of pleomorphic risk loci (PRL), i.e. individual genetic loci where several types of genetic risk for disease exist, including rare risk variants, common variants, and rare disease causing mutations [89]. As a general rule the genetics field has been most successful at identifying disease-causing mutations and common risk alleles. This latter category has been identified both by candidate gene association studies, which when performed in genes linked to monogenic forms of disease implicitly test the PRL hypothesis, and by genome wide association. There has been increasing interest in another area of the landscape of PRL, rare variants that exert moderate and minor risk. This category of risk alleles is often thought to be responsible for a major portion of the missing heritability of complex diseases such as PD. While there has been recent success in the identification of this type of risk variant in Alzheimer' disease $[90,91]$, the identification of such variants is challenging. This work usually requires very large sample series, and, particularly in the context of very rare variants, an ability to collapse groups of genetic variability into potential risk and potential protective prior to association testing. While this type of categorization is often performed computationally, based on a prediction of consequence (specifically protein coding consequence), there is the potential to incorporate expression and splicing consequences of rare variants into such a model. As with fine mapping of loci, it is likely that resequencing, in large series, will aid in the identification of rare risk alleles at the LRRK2 locus.

\section{THE FUNCTION OF LRRK2 AND ITS ROLE IN DISEASE}

As we have learned more about the genetics of LRRK2, the importance of this gene in Parkinson's has become ever clearer. It is a large leap, however, from human disease genetics to therapeutic targeting and one that is dependent upon a clear understanding of both protein structure and function. What, then, have we learned about the function of LRRK2 since mutations in the gene were first described? LRRK2 is a large multidomain enzyme, coupling kinase and GTPase activities with a number of protein/protein interaction domains [92]. It is one of a small number of 
proteins in the human genome that possess more than one enzymatic activity in the same open reading frame, an aspect of LRRK2s biology that is both attractive (as it presents two active sites to target) and complicates interpretation of both its normal cellular role and its dysfunction in the disease state. Over the last ten years a huge amount has been learned about the biochemistry and biology of LRRK2, and although a clearer picture is beginning to emerge regarding the consequences of mutations on the function of this protein there are still large gaps in our understanding of the pathogenic pathways that link LRRK2 to Parkinson's disease.

\section{Structural biology}

The complete open reading frame of LRRK2 codes for a 2527 amino acid protein, and initial domain prediction analysis of the primary sequence of LRRK2 identified two enzymatic domains: a GTPase and a kinase [93]. The GTPase domain was categorised as a Ras of Complex Proteins, or ROC, domain while the kinase domain has been variously described as belonging to the MAPKKK family, to the Mixed Lineage Kinases or to the RIP kinases [94]. Based purely upon the primary sequence of the kinase domain, LRRK2 is most closely linked to the RIP kinases. The two enzymatic domains of LRRK2 are separated by a domain of unknown function, a c-terminal of ROC (COR) domain, and are flanked by a number of protein/protein interaction motifs including a WD40 domain, the Leucine Rich Repeats that give the protein its name, and a series of repeats in the N-terminal region that have described as ankaryin repeats and armadillo repeats (Fig. 1) [95].

A number of atomic resolution structures have been reported for fragments of LRRK2 or closely related members of the same protein family. The first to be described was a fragment of human LRRK2 coding for the ROC domain of the protein, revealing a domain swap dimer structure [96]. Subsequent to this, a crystal structure has been elucidated for a prokaryotic homolog of LRRK2 isolated from Chlorobium tepidum, supporting a dimeric structure for this ROCO protein [97]. The chlorobium tepidum protein differs from LRRK2 in that it lacks a c-terminal kinase domain, but provides the first structural detail for the enigmatic COR domain - suggesting that this domain provides the key surfaces for dimeric interaction. Finally, the kinase domain of a LRRK2 ortholog from Dictyostelium has been crystalized and a $1.8 \AA$ structure derived [98]. It is noteworthy that the publically available structures for LRRK2 highlight the extent of the challenge that LRRK2 presents to structural biologists: thus far, only small fragments or homologs of LRRK2 have been purified to the point where structural studies are possible.

Based upon the published structures for LRRK2 and related proteins, Gasper and co-workers have proposed a model for ROCO protein function based upon Guanosine nucleotide dependent dimerization (GAD), classing LRRK2 as such a protein [99].

Other than purely structural approaches, a number of studies have been carried out to investigate the complex formed by LRRK2 under cellular or in vitro conditions. Using techniques such as size exclusion chromatography and blue native gel electrophoresis, several groups have reported that LRRK2 forms a complex consistent with a dimeric conformation [100-102], although there are reports in the literature that conflict with this [103]. Further studies using electron microscopy also support a dimeric conformation [104], and taking all of the extant data into consideration it is likely that dimerization plays an important part in the function of LRRK2 in a cellular context. A recent study using total internal reflection microscopy suggests that LRRK2 is predominantly monomeric in the cytoplasm, and forms a multimeric complex when associated with membranes [105]. The elucidation of the precise atomic structure of this complex, and the dynamics of this interaction in a functional context, remain a huge challenge.

\section{Enzymatic function}

The presence of two predicted enzymatic domains in the LRRK2 open reading frame has focused a considerable research effort on characterising and defining these activities. Soon after the description of mutations in LRRK2 linked to PD, a series of papers reported that LRRK2 was indeed an active kinase [106-108]. Similarly, several groups have reported that LRRK2 possesses a functional GTPase activity [109-111]. One of the many puzzling aspects of LRRK2 biology is how these two enzymatic activities relate to one another. Based upon a study investigating GTPase and kinase function in LRRK1, a close human homolog of LRRK2, which revealed that the kinase function of this protein was dependent upon GTP binding by the ROC domain [112], a number of publications have examined whether the kinase activity of LRRK2 has a similar requirement $[96,113-115]$. This led to the development of a model for LRRK2 enzymatic activity analogous to that applied to the small GTPases such 
as Ras, where the tightly controlled cycle between GTP and GDP bound states governs the activity of interacting kinases (in the case of Ras, the kinase Raf). More recent studies have suggested that the kinase activity of LRRK2 is dependent not upon whether GTP or GDP occupies the active site of the ROC domain, but upon whether there is a Guanosine nucleotide of any description within the active site [116]. Although by no means proving that the GAD model for LRRK2 function is correct, these data are certainly consistent with a Guanosine nucleotide dependent activation of kinase activity.

Intriguingly, there is accumulating evidence that the kinase activity of LRRK2 can be directed against its own ROC domain $[117,118]$, suggesting that there is a complex, reciprocal relationship between the enzymatic activities of this protein. Even more intriguing is a report that phosphorylation of the ROC domain can have a functional impact on the properties of this domain [119]. It should be noted that much of the data relating to phosphorylation of the ROC domain of LRRK2 derives from in vitro model systems, and this has not yet been demonstrated to be a physiologically relevant phenomenon, therefore caution should be exercised in interpreting these results.

Outside of the ROC/COR/Kinase enzymatic core of LRRK2, it has become clear that the far c-terminus of LRRK2 plays a crucial role in regulating the kinase activity of this protein. Loss of the WD40 domain ablates the kinase activity of LRRK2, and provocatively even the loss of the seven amino acids at the far c-terminus of LRRK2 (residues 2520-2527) results in a kinase inactive form of the protein $[120,121]$. How the WD40 domain can have such an impressive impact on kinase activity is not clear, and the impact of cterminal truncation on LRRK2s GTPase activity has not been thoroughly investigated. It is likely that the underlying mechanism relating the WD40 domain to the enzymatic activities of LRRK2 will not be completely clarified until detailed structural information describing the precise spatial relationships of the different domains of LRRK2 is elucidated.

One final aspect of the control of LRRK2 enzymatic activity, linking in with the GAD model for ROCO protein function, is the dependence of kinase activity in particular upon dimerization. Although it is technically challenging to determine whether this kinase activity is derived from one species of LRRK2 rather than another (dimeric versus monomeric), there is evidence from several experimental conditions that the kinase activity of LRRK2 is dependent upon dimerization [100, 101, 122]. Clearly, more work is needed to determine if dimerization is an absolute requirement for kinase activity or if multiple LRRK2 complexes are enzymatically active [123].

\section{Signaling pathways and cellular function}

The cellular function/functions of LRRK2 have been a matter of great debate ever since the initial report of mutations in LRRK2. Given its large size and complex domain structure, it is perhaps not surprising that LRRK2 has been implicated in a startling array of cellular tasks.

The starting point for many of these roles has been LRRK2s status as a kinase, GTPase and putative signalling scaffold $[92,124]$. A number of studies have placed LRRK2 in one of the many established signalling cascades, including the mTOR, ERK, WNT and TLR pathways (Figure) [125-128]. The key challenge for these studies has been the validation of LRRK2s involvement by the demonstration of a physiological LRRK2 dependent phosphorylation event, and, despite almost ten years of searching, a clear validated substrate for LRRK2 has yet to emerge.

One aspect of LRRK2 biology that has stood the test of repeated investigation is an interaction with 14-3-3 proteins, dependent upon phosphorylation at residues S910 and S935 [129-131]. Phosphorylation and binding of 14-3-3 proteins plays an important role in the cellular localisation of LRRK2, although the kinase(s) responsible for directly phosphorylating LRRK2 at these residues has not been identified. Indeed, studies of the cellular localisation of LRRK2 have provided some clues as to what it may be doing within the cell. Data from a number of groups, using a variety of approaches, suggests that LRRK2 can associate with membrane structures in the cell [132-134]. Biochemical studies and total internal reflection microscopy have provided evidence that LRRK2 can cycle between a cytosolic, monomeric form which has decreased activity, and a membrane associated, multimeric form that has a higher activity $[105,122]$.

With regard to the physiological processes that these cascades link LRRK2 to, the recurring cellular themes are vesicle cycling, autophagy, miRNA processing and cytoskeletal regulation (Fig. 3). It is not yet clear if these represent independent or convergent roles for LRRK2, and it is certainly not beyond the bounds of possibility that LRRK2 might have important roles in a number of cellular processes given its complicated domain structure [123].

A number of studies have highlighted a role for LRRK2 in the regulation of synaptic vesicles [135, 


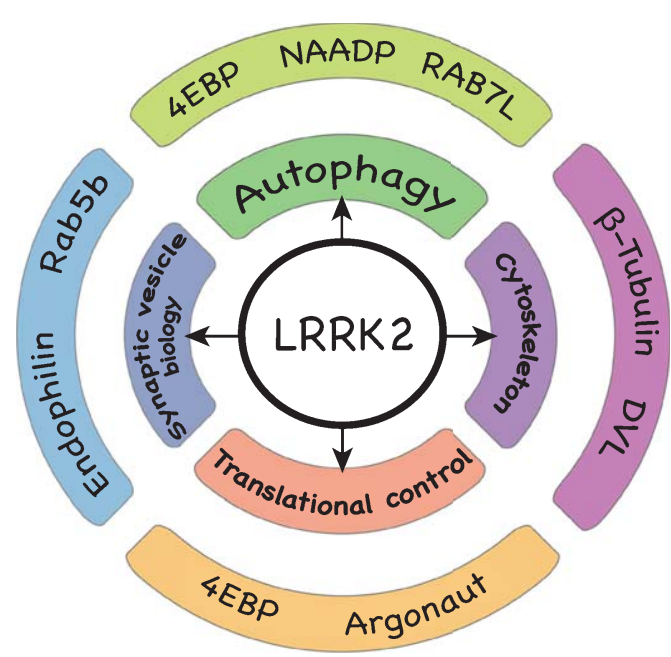

Fig. 3. The biology of LRRK2. LRRK2 has been implicated in a host of different cellular processes.

136], with Matta and coworkers demonstrating that LRRK2 interacts directly with endophilins to exert an influence on vesicle endocytosis. Further evidence of a role for LRRK2 in vesicular biology comes from studies linking LRRK2 to cellular macroautophagy [128, 137-139], although it is not clear precisely how LRRK2 impacts on this process. A strong line of evidence supporting a role for LRRK2 in autophagy, albeit a complicated role, comes from studies of mice lacking LRRK2 [140, 141]. In these mice, knockout of LRRK2 results in a kidney phenotype marked by inclusions and by alterations in markers for autophagy - although again the precise reason why this occurs is not clear. The complications arise from an apparent biphasic impact on autophagy, with autophagic markers altering through development. A more recent study has implicated LRRK2 in chaperone-mediated autophagy (CMA), suggesting that alterations in LRRK2 can result in defective CMA [142]. Macleod and coworkers have reported LRRK2 interacting with Rab7L1 to influence protein sorting, including lysosomal protein sorting, via the retromer complex - suggesting that multiple systems surrounding protein disposal can be adversely impacted by LRRK2 [143].

As noted above, miRNA regulation is another recurring theme in LRRK2 biology. Gehrke and colleagues described LRRK2 regulating let-7 and miR-184* to control protein translation, with a subsequent study by Cho et al reporting LRRK2 levels being regulated in turn by miR-205 [144, 145]. How LRRK2 regulates, and is regulated by, miRNAs is an area of active investigation. It will be of particular interest to discover if these interactions have a consistent pathological role in human cell models and brain tissue.

LRRK2 has been identified as interacting with a number of cytoskeletal proteins, including $\beta$ Tubulin [146, 147], actin [148] and Moesin [120]. There is increasing evidence linking LRRK2 to a functional role in the control of cytoskeletal remodeling, which is of particular interest given that one of the more robust cellular phenotypes associated with LRRK2, alterations in neurite branching, can be impacted by this [149, 150].

One area of LRRK2 biology that is under increasing scrutiny is a putative role in the immune system. It has long been noted that LRRK2 is highly expressed in immune cells, and several studies have shown that LRRK2 is involved in the response to pathogens and interferon $\gamma[151,152]$. Intriguingly, the LRRK2 locus been implicated in Crohn's disease and susceptibility to leprosy, providing a genetic link to immune disease $[153,154]$ and recent studies have highlighted a potential role in microglial response within the brain [155, 156]. How these data tie in to the cellular biology of LRRK2 is unclear, but this is certainly an area that merits further investigation.

\section{Mutations in LRRK2 and their impact on biology}

The central question in LRRK2 biology, and the question that drives the majority of research into this protein, is straightforward: how do the mutations in LRRK2 linked to PD result in disease? The answer, unfortunately, is convoluted. From a genetic standpoint, as highlighted earlier in this article, it is clear that the enzymatic core of LRRK2 is central to the role of this protein in neurodegeneration as the penetrant mutations unambiguously linked to disease all cluster within the ROC/COR/kinase triptych of domains [17]. To date, however, no consistent biochemical impact of these mutations has been reported (Table 1). Mutations in the ROC and COR domains (for example those at codon 1441 and the p.Y1699C mutation) act to decrease GTPase activity by an as yet undefined mechanism, although based on the GAD model for LRRK2 function one could hypothesise a disruptive influence on dimer formation for both of these residues. A detailed characterisation of the impact of mutations in the kinase domain (either the p.G2019S or p.I2020T mutants) upon GTPase activity of full length LRRK2 has not yet been carried out, however the p.G2019S mutation results in a $20 \%$ reduction in GTPase activity compared to wild type LRRK2 in assays using a truncated recombinant form of the protein [157]. This 
Table 1

Summary of the impact of mutations in LRRK2 on biochemical readouts for LRRK2 function

\begin{tabular}{lccc}
\hline Mutation & Domain & Enzymatic impact & 14-3-3 binding \\
\hline p.N1437H & ROC & Unknown & Unknown \\
p.R1441C & ROC & GTPase $\downarrow$ & $\downarrow$ \\
p.R1441G & ROC & GTPase $\downarrow$ & $\downarrow$ \\
p.Y1699C & COR & GTPase $\downarrow$ & $\downarrow$ \\
p.S1761R & COR & Unknown & Unknown \\
p.I2012T & Kinase & None & $\downarrow$ \\
p.G2019S & Kinase & Kinase $\uparrow$ GTPase $\downarrow$ & No change \\
p.I2020T & Kinase & None & $\downarrow$ \\
p.G2385R & WD40 & Kinase $\downarrow$ & No change \\
\hline
\end{tabular}

suggests that the GTPase activity of LRRK2 is certainly worthy of further investigation. The impact of mutations throughout the ROC/COR/kinase domains upon kinase activity has been assessed by a number of groups, with a substantial and consistent impact noted for p.G2019S but not other mutations (including the p.I2020T mutation, located at the residue next to p.G2019) [158]. In a surprising twist, a recent study has suggested that a risk variant in the WD40 domain of LRRK2 found associated with PD in asian populations (the p.G2385R polymorphism) substantially decreases the kinase activity of LRRK2 - the opposite of the impact of the p.G2019S mutation [121]. If correct, this result has profound implications for the development of inhibitors targeting the kinase activity of LRRK2 as a therapeutic avenue. An example of the complexities of enzymatic activities and inhibition in a cellular context is presented by a recent analysis of Wnt signaling linked to LRRK2 - with both mutations (including the p.G2019S mutation, and therefore a hyperactive kinase) and kinase inhibition resulting in the same cellular alteration in Wnt signaling [124]. A comprehensive analysis of the impact of mutations on the folding and turnover of LRRK2 has not been reported, however there are suggestions that the p.R1441C and p.I2020T mutations could alter protein stability and/or protein turnover - which would, of course, have a significant impact on enzymatic activity $[159,160]$. Despite almost ten years of research, we are still unsure as to what aspect of LRRK2s biochemistry we should be concentrating on in the context of Parkinson's disease. If any theme emerges looking across the extant literature covering the biochemical impact of mutations in LRRK2, it is that disruption of enzymatic activity - whether up or down, kinase or GTPase - can be deleterious. This suggests a model where LRRK2 activity is tightly regulated within cells, and it is the disruption of this regulation regardless of the direction that results in the instigation of disease.
Unfortunately the picture is just as murky when the impact of LRRK2 mutations on cellular phenotypes is considered. One of the few consistent aspects of LRRK2 mutations in a cellular context is that they display increased toxicity compared to the wild type protein, and this toxicity is dependent upon kinase activity [108, 115]. What drives this toxicity is not known, although there is no shortage of possibilities - ranging from FADD signalling through to changes in translational regulation $[144,161]$. A major stumbling block, similar to that encountered when assessing the biochemical impact of mutations in LRRK2, is that different mutations quite often have different outcomes with regard to a given cellular readout. A good example of this is provided by the robust interaction between LRRK2 and 14-3-3 [129, 130]. While the p.R1441G, p.Y1699C and p.I2020T mutants all have a major impact on the phosphorylation of LRRK2 at p.S910 and p.S935 (and thus a decreased binding of LRRK2 to 14-3-3), the common p.G2019S mutant does not. Conversely, a number of cellular phenotypes linked to PD mutations in LRRK2 - for example the impact on miRNA processing described by Gehrke and coworkers - alter in the presence of the p.G2019S mutation, but not other mutations. This poses a particular conundrum to researchers: we know that kinase activity is important for LRRK2 and its pathogenic impact, and we know that the p.G2019S mutation that alters kinase activity is the most common mutation in LRRK2, but it is equally clear that kinase activity, or at least a simple increase in this activity, is not the only factor in the pathogenic process. The challenge, therefore, is to distinguish between phenotypes that are primarily driven by the kinase activity of LRRK2 (particularly the case with the p.G2019S mutation) and those that are truly associated with disease. One obvious way to address this is to examine mutations in each of the domains of LRRK2, for example the p.R1441G, p.Y1699C and p.G2019S substitutions (with the possible addition of the $\mathrm{p} . \mathrm{G} 2385 \mathrm{R}$ polymorphism in the WD40 domain), for any phenotype that is suspected to link with LRRK2. It is of course conceivable that different mutations in LRRK2 have different mechanisms of action, but, given the consistent clinical phenotype associated with LRRK2 mutations, it is highly likely that there is a property that unites all of the mutations in LRRK2 - the problem is that we haven't found it yet.

\section{Animal models for LRRK2 dysfunction}

Given the interest in LRRK2 and its role in PD, it is perhaps not surprising that a large number of 
animal models for LRRK2 dysfunction have been developed. Drosophila melanogaster, Danio rerio and Caenorhabditis elegans models have been developed, including knockout, knockdown and overexpression of the human protein (plus and minus mutations) or the equivalent fly, fish or worm orthologs [125, 162-168]. The interpretation of the data from these models is complicated by the relationship between human LRRK2 and the LRRK genes found in these species: in all three cases there is only one LRRK gene, and whether this corresponds to human LRRK1 or LRRK2 is a matter of some debate [169].

Rodents, in contrast, have orthologs of both human LRRK genes and a number of mouse and rat models for LRRK2 have been developed over the last nine years (summarised in reference [170]). In common with rodent models for other genes linked to Parkinson's disease, these have proved to be somewhat disappointing in terms of replicating a phenotype that is equivalent to the human disorder [171]. Important insights into LRRK2 dysfunction have been gained, however, by detailed analysis of these models. A putative role for LRRK2 in modulating alpha synuclein pathology was reported by Lin and co-workers examining transgenic mice expressing LRRK2 and the p.A53T form of alpha-synuclein, and several models using both BAC expression of LRRK2 mutants and viral mediated acute expression have reported accumulation of tau [172-175]. These findings are particularly interesting in the light of the varied pathology observed in human LRRK2 mutation carriers. Echoing the vesicular data from cellular models, the p.R1441C mutation impacts on dopamine cycling in mice [176]. The extant transgenic models for LRRK2 do not, on the whole, present with neuronal degeneration, however acute expression of LRRK2 via viral transduction provides evidence of direct neuronal toxicity in an in vivo setting $[177,178]$. How this acute expression relates to the drawn out pathogenic process seen in human PD is unclear. Knock out rodent models for LRRK2 have likewise revealed important insights into LRRK2 biology - providing evidence of a link to autophagy and to Crohn's disease [140, 179].

\section{Future functional challenges}

As is abundantly obvious from this brief summary of our current understanding of LRRK2 biology, there are many challenges still to be met before we have a complete picture of LRRK2s function and how this is perverted in Parkinson's disease. Two even larger challenges are on the horizon. First, and dependent upon elucidation of the role of mutations in LRRK2 in the pathological cascade that leads to Parkinson's disease, will be how to correct their impact. Based upon the indubitable importance of kinase activity in the aetiopathogenesis of LRRK2 linked PD, there is a concerted effort underway to develop inhibitors of LRRK2 kinase activity [180]. It is by no means clear, however, if this approach will succeed in a clinical setting - although it is likely that LRRK2 kinase inhibitors will be tested in a clinical trial sooner rather than later.

The second major challenge is to dissect the role of $L R R K 2$ in sporadic PD. The scale of this challenge on a cellular scale is difficult to underestimate. We have, to date, struggled to decipher what mutations in LRRK2 strongly associated with disease do to the brain. How much more difficult will it be to understand how subtle variation at the $L R R K 2$ locus, accounting for a fraction of a percentage point of increased life time risk for $\mathrm{PD}$, impacts of the pathogenesis of this disorder? At present it is not known what the association uncovered by the GWA studies at the LRRK2 locus represents, and indeed uncovering exactly what the association drives at a functional level may be no small feat in itself.

\section{Summary}

The field has made enormous progress since the discovery of LRRK2 mutations in 2004. Our understanding of the genetic basis of this disease has increased exponentially since this time, and it is clear that varied forms of $L R R K 2$ exert many different types of influence on the disease process. Likewise, while there is still a long way to go in understanding the pathobiological basis of PD, LRRK2 mutations have provided valuable insights into this process, and the tools with which to understand more. We believe that this is an exciting time in PD research, and we believe that LRRK2 will be central to this effort for a long time to come.

\section{ACKNOWLEDGEMENTS}

P.A.L. is a Parkinson's UK research fellow (grant F1002) and thanks the Michael J. Fox Foundation for generous research support. This work was supported in part by the Wellcome Trust/MRC Joint Call in Neurodegeneration award (WT089698) to the UK Parkinson's Disease Consortium (UKPDC) whose members are from the UCL Institute of Neurology, the University of Sheffield and the MRC Protein Phosphorylation Unit at the University of Dundee. This 
work was supported in part by the National Institute of Neurological Disorders and Stroke of the National Institutes of Health under award number R01NS079388 to C.P.R. This work is supported in part by the Intramural Research Program of the National Institute on Aging, National Institutes of Health, part of the Department of Health and Human Services; project numbers ZO1 AG000949-07 and ZO1 AG000958-10.

\section{REFERENCES}

[1] Paisan-Ruiz C, Jain S, Evans EW, Gilks WP, Simon J, van der Brug M, Lopez de Munain A, Aparicio S, Gil AM, Khan N, Johnson J, Martinez JR, Nicholl D, Carrera IM, Pena AS, de Silva R, Lees A, Marti-Masso JF, Perez-Tur J, Wood NW, \& Singleton AB (2004) Cloning of the gene containing mutations that cause PARK8-linked Parkinson's disease. Neuron, 44, 595-600.

[2] Zimprich A, Biskup S, Leitner P, Lichtner P, Farrer M, Lincoln S, Kachergus J, Hulihan M, Uitti RJ, Calne DB, Stoessl AJ, Pfeiffer RF, Patenge N, Carbajal IC, Vieregge P, Asmus F, Muller-Myhsok B, Dickson DW, Meitinger T, Strom TM, Wszolek ZK, \& Gasser T(2004) Mutations in LRRK2 cause autosomal-dominant parkinsonism with pleomorphic pathology. Neuron, 44, 601-607.

[3] Rubio JP, Topp S, Warren L, St Jean PL, Wegmann D, Kessner D, Novembre J, Shen J, Fraser D, Aponte J, Nangle K, Cardon LR, Ehm MG, Chissoe SL, Whittaker JC, Nelson MR, \& Mooser VE (2012) Deep sequencing of the LRRK2 gene in 14,002 individuals reveals evidence of purifying selection and independent origin of the p. Arg1628Pro mutation in Europe. Hum Mutat, 33, 1087-1098.

[4] Aasly JO, Vilarino-Guell C, Dachsel JC, Webber PJ, West AB, Haugarvoll K, Johansen KK, Toft M, Nutt JG, Payami H, Kachergus JM, Lincoln SJ, Felic A, Wider C, SotoOrtolaza AI, Cobb SA, White LR, Ross OA, \& Farrer MJ (2010) Novel pathogenic LRRK2 p. Asn1437His substitution in familial Parkinson's disease. Mov Disord, 25, 2156-2163.

[5] Bardien S, Lesage S, Brice A, \& Carr J (2011) Genetic characteristics of leucine-rich repeat kinase 2 (LRRK2) associated Parkinson's disease. Parkinsonism Relat Disord, 17, 501-508.

[6] Lorenzo-Betancor O, Samaranch L, Ezquerra M, Tolosa E, Lorenzo E, Irigoyen J, Gaig C, Pastor MA, Soto-Ortolaza AI, Ross OA, Rodriguez-Oroz MC, Valldeoriola F, Marti MJ, Luquin MR, Perez-Tur J, Burguera JA, Obeso JA, \& Pastor P (2011) LRRK2 haplotype-sharing analysis in Parkinson's disease reveals a novel p. S1761R mutation. Mov Disord, 27, 146-151.

[7] Paisan-Ruiz C (2009) LRRK2 gene variation and its contribution to Parkinson disease. Hum Mutat, 30, 1153-1160.

[8] Correia Guedes L, Ferreira JJ, Rosa MM, Coelho M, Bonifati V, \& Sampaio C (2010) Worldwide frequency of G2019S LRRK2 mutation in Parkinson's disease: A systematic review. Parkinsonism Relat Disord, 16, 237-242.

[9] Bras JM, Guerreiro RJ, Ribeiro MH, Januario C, Morgadinho A, Oliveira CR, Cunha L, Hardy J, \& Singleton A (2005) G2019S dardarin substitution is a common cause of Parkinson's disease in a Portuguese cohort. Mov Disord, 20, 1653-1655.
[10] Lesage S, Leutenegger AL, Ibanez P, Janin S, Lohmann E, Durr A, \& Brice A (2005) LRRK2 haplotype analyses in European and North African families with Parkinson disease: A common founder for the G2019S mutation dating from the 13th century. Am J Hum Genet, 77, 330-332.

[11] Ozelius LJ, Senthil G, Saunders-Pullman R, Ohmann E, Deligtisch A, Tagliati M, Hunt AL, Klein C, Henick B, Hailpern SM, Lipton RB, Soto-Valencia J, Risch N, \& Bressman SB (2006) LRRK2 G2019S as a cause of Parkinson's disease in Ashkenazi Jews. N Engl J Med, 354, 424-425.

[12] Deng H, Le W, Guo Y, Hunter CB, Xie W, Huang M, \& Jankovic J (2006) Genetic analysis of LRRK2 mutations in patients with Parkinson disease. J Neurol Sci, 251, 102-106.

[13] Mata IF, Cosentino C, Marca V, Torres L, Mazzetti P, Ortega O, Raggio V, Aljanati R, Buzo R, Yearout D, Dieguez E, \& Zabetian CP (2009) LRRK2 mutations in patients with Parkinson's disease from Peru and Uruguay. Parkinsonism Relat Disord, 15, 370-373.

[14] Yescas P, Lopez M, Monroy N, Boll MC, RodriguezViolante M, Rodriguez U, Ochoa A, \& Alonso ME (2010) Low frequency of common LRRK2 mutations in Mexican patients with Parkinson's disease. Neurosci Lett, 485, 79-82.

[15] Gorostidi A, Ruiz-Martinez J, Lopez de Munain A, Alzualde A, \& Marti Masso JF (2009) LRRK2 G2019S and R1441G mutations associated with Parkinson's disease are common in the Basque Country, but relative prevalence is determined by ethnicity. Neurogenetics, 10, 157-159.

[16] Nuytemans K, Rademakers R, Theuns J, Pals P, Engelborghs S, Pickut B, de Pooter T, Peeters K, Mattheijssens M, Van den Broeck M, Cras P, De Deyn PP, \& van Broeckhoven C (2008) Founder mutation p. R1441C in the leucine-rich repeat kinase 2 gene in Belgian Parkinson's disease patients. Eur J Hum Genet, 16, 471-479.

[17] Ross OA, Soto-Ortolaza AI, Heckman MG, Aasly JO, Abahuni N, Annesi G, Bacon JA, Bardien S, Bozi M, Brice A, Brighina L, Van Broeckhoven C, Carr J, ChartierHarlin M-C, Dardiotis E, Dickson DW, Diehl NN, Elbaz A, Ferrarese C, Ferraris A, Fiske B, Gibson JM, Gibson R, Hadjigeorgiou GM, Hattori N, Ioannidis JPA, Jasinska-Myga B, Jeon BS, Kim YJ, Klein C, Kruger R, Kyratzi E, Lesage S, Lin C-H, Lynch T, Maraganore DM, Mellick GD, Mutez E, Nilsson C, Opala G, Park SS, Puschmann A, Quattrone A, Sharma M, Silburn PA, Sohn YH, Stefanis L, Tadic V, Theuns J, Tomiyama H, Uitti RJ, Valente EM, van de Loo S, Vassilatis DK, Vilariño-Güell C, White LR, Wirdefeldt K, Wszolek ZK, Wu R-M, \& Farrer MJ (2011) Association of LRRK2 exonic variants with susceptibility to Parkinson's disease: A case-control study. Lancet Neurol, 10, 898-908.

[18] Ross OA, Spanaki C, Griffith A, Lin CH, Kachergus J, Haugarvoll K, Latsoudis H, Plaitakis A, Ferreira JJ, Sampaio C, Bonifati V, Wu RM, Zabetian CP, \& Farrer MJ (2009) Haplotype analysis of Lrrk2 R1441H carriers with parkinsonism. Parkinsonism Relat Disord, 15, 466-467.

[19] Funayama M, Hasegawa K, Ohta E, Kawashima N, Komiyama M, Kowa H, Tsuji S, \& Obata F (2005) An LRRK2 mutation as a cause for the parkinsonism in the original PARK8 family. Ann Neurol, 57, 918-921.

[20] Kim JS, Cho JW, Shin H, Lee WY, Ki CS, Cho AR, \& Kim HT (2012) A Korean Parkinson's disease family with the LRRK2 p. Tyr1699Cys mutation showing clinical heterogeneity. Mov Disord 27, 320-324.

[21] Marras C, Schule B, Munhoz RP, Rogaeva E, Langston JW, Kasten M, Meaney C, Klein C, Wadia PM, Lim SY, Chuang RS, Zadikof C, Steeves T, Prakash KM, de Bie RM, Adeli G, Thomsen T, Johansen KK, Teive HA, Asante A, 
Reginold W, \& Lang AE (2011) Phenotype in parkinsonian and nonparkinsonian LRRK2 G2019S mutation carriers. Neurology, 77, 325-333.

[22] Healy DG, Falchi M, O'Sullivan SS, Bonifati V, Durr A, Bressman S, Brice A, Aasly J, Zabetian CP, Goldwurm S, Ferreira JJ, Tolosa E, Kay DM, Klein C, Williams DR, Marras C, Lang AE, Wszolek ZK, Berciano J, Schapira AH, Lynch T, Bhatia KP, Gasser T, Lees AJ, \& Wood NW (2008) Phenotype, genotype, and worldwide genetic penetrance of LRRK2-associated Parkinson's disease: A case-control study. Lancet Neurol, 7, 583-590.

[23] Aasly JO, Toft M, Fernandez-Mata I, Kachergus J, Hulihan M, White LR, \& Farrer M (2005) Clinical features of LRRK2-associated Parkinson's disease in central Norway. Ann Neurol, 57, 762-765.

[24] Alcalay RN, Mejia-Santana H, Tang MX, Rakitin B, Rosado L, Ross B, Verbitsky M, Kisselev S, Louis ED, Comella CL, Colcher A, Jennings D, Nance MA, Bressman S, Scott WK, Tanner C, Mickel SF, Andrews HF, Waters CH, Fahn S, Cote LJ, Frucht SJ, Ford B, Rezak M, Novak K, Friedman JH, Pfeiffer R, Marsh L, Hiner B, Siderowf A, Ottman R, Clark LN, Marder KS, \& Caccappolo E (2010) Self-report of cognitive impairment and mini-mental state examination performance in PRKN, LRRK2, and GBA carriers with early onset Parkinson's disease. J Clin Exp Neuropsychol, 32, 775779.

[25] Goldwurm S, Zini M, Di Fonzo A, De Gaspari D, Siri C, Simons EJ, van Doeselaar M, Tesei S, Antonini A, Canesi M, Zecchinelli A, Mariani C, Meucci N, Sacilotto G, Cilia R, Isaias IU, Bonetti A, Sironi F, Ricca S, Oostra BA, Bonifati V, \& Pezzoli G (2006) LRRK2 G2019S mutation and Parkinson's disease: A clinical, neuropsychological and neuropsychiatric study in a large Italian sample. Parkinsonism Relat Disord, 12, 410-419.

[26] Shanker V, Groves M, Heiman G, Palmese C, SaundersPullman R, Ozelius L, Raymond D, \& Bressman S (2011) Mood and cognition in leucine-rich repeat kinase 2 G2019S Parkinson's disease. Mov Disord, 26, 1875-1880.

[27] Yahalom G, Kaplan N, Vituri A, Cohen OS, Inzelberg R, Kozlova E, Korczyn AD, Rosset S, Friedman E, \& HassinBaer S (2012) Dyskinesias in patients with Parkinson's disease: Effect of the leucine-rich repeat kinase 2 (LRRK2) G2019S mutation. Parkinsonism Relat Disord, 18, 10391041.

[28] Kachergus J, Mata IF, Hulihan M, Taylor JP, Lincoln S, Aasly J, Gibson JM, Ross OA, Lynch T, Wiley J, Payami H, Nutt J, Maraganore DM, Czyzewski K, Styczynska M, Wszolek ZK, Farrer MJ, \& Toft M (2005) Identification of a novel LRRK2 mutation linked to autosomal dominant parkinsonism: Evidence of a common founder across European populations. Am J Hum Genet, 76, 672-680.

[29] San Luciano M, Lipton RB, Wang C, Katz M, Zimmerman ME, Sanders AE, Ozelius LJ, Bressman SB, \& SaundersPullman R (2010) Clinical expression of LRRK2 G2019S mutations in the elderly. Mov Disord, 25, 2571-2576.

[30] Thaler A, Mirelman A, Gurevich T, Simon E, Orr-Urtreger A, Marder K, Bressman S, \& Giladi N (2012) Lower cognitive performance in healthy G2019S LRRK2 mutation carriers. Neurology, 79, 1027-1032.

[31] Mirelman A, Gurevich T, Giladi N, Bar-Shira A, Orr-Urtreger A, \& Hausdorff JM (2011) Gait alterations in healthy carriers of the LRRK2 G2019S mutation. Ann Neurol, 69, 193-197.

[32] Ponsen MM, Stoffers D, Booij J, van Eck-Smit BL, Wolters Ec, \& Berendse HW (2004) Idiopathic hyposmia as a preclinical sign of Parkinson's disease. Ann Neurol, 56, 173181.

[33] Katzenschlager R, \& Lees AJ (2004) Olfaction and Parkinson's syndromes: Its role in differential diagnosis. Curr Opin Neurol, 17, 417-423.

[34] Saunders-Pullman R, Stanley K, Wang C, San Luciano M, Shanker V, Hunt A, Severt L, Raymond D, Ozelius LJ, Lipton RB, \& Bressman SB (2011) Olfactory dysfunction in LRRK2 G2019S mutation carriers. Neurology, 77, 319-324.

[35] Silveira-Moriyama L, Munhoz RP, de JCM, Raskin S, Rogaeva E, de CAP, Bressan RA, Felicio AC, Barsottini OG, Andrade LA, Chien HF, Bonifati V, Barbosa ER, Teive HA, \& Lees AJ (2010) Olfactory heterogeneity in LRRK2 related Parkinsonism. Mov Disord, 25, 2879-2883.

[36] Ruiz-Martinez J, Gorostidi A, Goyenechea E, Alzualde A, Poza JJ, Rodriguez F, Bergareche A, Moreno F, Lopez de Munain A, \& Marti Masso JF (2011) Olfactory deficits and cardiac 123I-MIBG in Parkinson's disease related to the LRRK2 R1441G and G2019S mutations. Mov Disord, 26, 2026-2031.

[37] Sierra M, Sanchez-Juan P, Martinez-Rodriguez MI, Gonzalez-Aramburu I, Garcia-Gorostiaga I, Quirce MR, Palacio E, Carril JM, Berciano J, Combarros O, Infante J (2013) Olfaction and imaging biomarkers in premotor LRRK2 G2019S-associated Parkinson disease. Neurology, 80, 621-626.

[38] Santpere G, \& Ferrer I (2009) LRRK2 and neurodegeneration. Acta Neuropathol, 117, 227-246.

[39] Wider C, Dickson DW, \& Wszolek ZK (2010) Leucinerich repeat kinase 2 gene-associated disease: Redefining genotype-phenotype correlation. Neurodegener Dis, 7, 175179.

[40] Ruffmann C, Giaccone G, Canesi M, Bramerio M, Goldwurm S, Gambacorta M, Rossi G, Tagliavini F, \& Pezzoli G (2012) Atypical tauopathy in a patient with LRRK2-G2019S mutation and tremor-dominant Parkinsonism. Neuropathol Appl Neurobiol, 38, 382-386.

[41] Ujiie S, Hatano T, Kubo S, Imai S, Sato S, Uchihara T, Yagishita S, Hasegawa K, Kowa H, Sakai F, \& Hattori N (2012) LRRK2 I2020T mutation is associated with tau pathology. Parkinsonism Relat Disord, 18, 819-823.

[42] Khan NL, Jain S, Lynch JM, Pavese N, Abou-Sleiman P, Holton JL, Healy DG, Gilks WP, Sweeney MG, Ganguly M, Gibbons V, Gandhi S, Vaughan J, Eunson LH, Katzenschlager R, Gayton J, Lennox G, Revesz T, Nicholl D, Bhatia KP, Quinn N, Brooks D, Lees AJ, Davis MB, Piccini P, Singleton AB, \& Wood NW (2005) Mutations in the gene LRRK2 encoding dardarin (PARK8) cause familial Parkinson's disease: Clinical, pathological, olfactory and functional imaging and genetic data. Brain, 128, 27862796.

[43] Wszolek ZK, Vieregge P, Uitti RJ, Gasser T, Yasuhara O, McGeer P, Berry K, Calne DB, Vingerhoets FJ, Klein C, \& Pfeiffer RF (1997) German-Canadian family (family A) with parkinsonism, amyotrophy, and dementia - Longitudinal observations. Parkinsonism Relat Disord, 3, 125-139.

[44] Wszolek ZK, Pfeiffer RF, Tsuboi Y, Uitti RJ, McComb RD, Stoessl AJ, Strongosky AJ, Zimprich A, Muller-Myhsok B, Farrer MJ, Gasser T, Calne DB, \& Dickson DW (2004) Autosomal dominant parkinsonism associated with variable synuclein and tau pathology. Neurology, 62, 1619-1622.

[45] Marti-Masso JF, Ruiz-Martinez J, Bolano MJ, Ruiz I, Gorostidi A, Moreno F, Ferrer I, \& Lopez de Munain A (2009) Neuropathology of Parkinson's disease with the R1441G mutation in LRRK2. Mov Disord, 24, 1998-2001. 
[46] Puschmann A, Englund E, Ross OA, Vilarino-Guell C, Lincoln SJ, Kachergus JM, Cobb SA, Tornqvist AL, Rehncrona S, Widner H, Wszolek ZK, Farrer MJ, \& Nilsson C (2011) First neuropathological description of a patient with Parkinson's disease and LRRK2 p. N1437H mutation. Parkinsonism Relat Disord, 18, 332-338.

[47] Simon-Sanchez J, Schulte C, Bras JM, Sharma M, Gibbs JR, Berg D, Paisan-Ruiz C, Lichtner P, Scholz SW, Hernandez DG, Kruger R, Federoff M, Klein C, Goate A, Perlmutter J, Bonin M, Nalls MA, Illig T, Gieger C, Houlden H, Steffens M, Okun MS, Racette BA, Cookson MR, Foote KD, Fernandez HH, Traynor BJ, Schreiber S, Arepalli S, Zonozi R, Gwinn K, van der Brug M, Lopez G, Chanock SJ, Schatzkin A, Park Y, Hollenbeck A, Gao J, Huang X, Wood NW, Lorenz D, Deuschl G, Chen H, Riess O, Hardy JA, Singleton AB, \& Gasser T (2009) Genome-wide association study reveals genetic risk underlying Parkinson's disease. Nat Genet, 41, 1308-1312.

[48] Gan-Or Z, Bar-Shira A, Mirelman A, Gurevich T, Giladi N, \& Orr-Urtreger A (2012) The age at motor symptoms onset in LRRK2-associated Parkinson's disease is affected by a variation in the MAPT locus: A possible interaction. $J$ Mol Neurosci, 46, 541-544.

[49] Golub Y, Berg D, Calne DB, Pfeiffer RF, Uitti RJ, Stoessl AJ, Wszolek ZK, Farrer MJ, Mueller JC, Gasser T, \& Fuchs J (2009) Genetic factors influencing age at onset in LRRK2linked Parkinson disease. Parkinsonism Relat Disord, 15, 539-541.

[50] Cardo LF, Coto E, de Mena L, Ribacoba R, LorenzoBetancor O, Pastor P, Samaranch L, Mata IF, Diaz M, Moris G, Menendez M, Corao AI, \& Alvarez V (2012) A search for SNCA 3' UTR variants identified SNP rs356165 as a determinant of disease risk and onset age in Parkinson's disease. J Mol Neurosci, 47, 425-430.

[51] Botta-Orfila T, Ezquerra M, Pastor P, Fernandez-Santiago $\mathrm{R}$, Pont-Sunyer C, Compta Y, Lorenzo-Betancor O, Samaranch L, Marti MJ, Valldeoriola F, Calopa M, Fernandez M, Aguilar M, de Fabregas O, Hernandez-Vara J, \& Tolosa E (2012) Age at onset in LRRK2-associated PD is modified by SNCA variants. J Mol Neurosci, 48, 245-247.

[52] Biskup S, Mueller JC, Sharma M, Lichtner P, Zimprich A, Berg D, Wüllner U, Illig T, Meitinger T, \& Gasser T (2005) Common variants of LRRK2 are not associated with sporadic Parkinson's disease. Ann Neurol, 58, 905-908.

[53] Paisán-Ruíz C, Lang AE, Kawarai T, Sato C, Salehi-Rad S, Fisman GK, Al-Khairallah T, St George-Hyslop P, Singleton A, \& Rogaeva E (2005) LRRK2 gene in Parkinson disease: Mutation analysis and case control association study. Neurology, 65, 696-700.

[54] Paisán-Ruíz C, Evans EW, Jain S, Xiromerisiou G, Gibbs JR, Eerola J, Gourbali V, Hellström O, Duckworth J, Papadimitriou A, Tienari PJ, Hadjigeorgiou GM, \& Singleton AB (2006) Testing association between LRRK2 and Parkinson's disease and investigating linkage disequilibrium. $J$ Med Genet, 43, e9.

[55] Mata IF, Kachergus JM, Taylor JP, Lincoln S, Aasly J, Lynch T, Hulihan MM, Cobb SA, Wu R-M, Lu C-S, Lahoz C, Wszolek ZK, \& Farrer MJ (2005) Lrrk2 pathogenic substitutions in Parkinson's disease. Neurogenetics, 6, 171-177.

[56] Di Fonzo A, Wu-Chou Y-H, Lu C-S, van Doeselaar M, Simons EJ, Rohé CF, Chang H-C, Chen R-S, Weng Y-H, Vanacore N, Breedveld GJ, Oostra BA, \& Bonifati V (2006) A common missense variant in the LRRK2 gene, Gly2385Arg, associated with Parkinson's disease risk in Taiwan. Neurogenetics, 7, 133-138.
[57] Tan EK, Zhao Y, Skipper L, Tan MG, Di Fonzo A, Sun L, Fook-Chong S, Tang S, Chua E, Yuen Y, Tan L, Pavanni R, Wong MC, Kolatkar P, Lu CS, Bonifati V, \& Liu JJ (2007) The LRRK2 Gly2385Arg variant is associated with Parkinson's disease: Genetic and functional evidence. Hum Genet, 120, $857-863$.

[58] Fung H-C, Chen C-M, Hardy J, Singleton AB, \& Wu Y-R (2006) A common genetic factor for Parkinson disease in ethnic Chinese population in Taiwan. BMC Neurol, 6,47

[59] Li C, Ting Z, Qin X, Ying W, Li B, Guo Qiang L, Jian Fang M, Jing Z, Jian Qing D, \& Sheng Di C (2007) The prevalence of LRRK2 Gly2385Arg variant in Chinese Han population with Parkinson's disease. Mov Disord, 22, 2439-2443.

[60] Tan E-K, Zhao Y, Tan L, Lim H-Q, Lee J, Yuen Y, Pavanni R, Wong M-C, Fook-Chong S, \& Liu J-J (2007) Analysis of LRRK2 Gly2385Arg genetic variant in non-Chinese Asians. Mov Disord, 22, 1816-1818.

[61] Funayama M, Li Y, Tomiyama H, Yoshino H, Imamichi Y, Yamamoto M, Murata M, Toda T, Mizuno Y, \& Hattori N (2007) Leucine-rich repeat kinase 2 G2385R variant is a risk factor for Parkinson disease in Asian population. Neuroreport, 18, 273-275.

[62] Chan DKY, Ng PW, Mok V, Yeung J, Fang ZM, Clarke R, Leung E, \& Wong L (2008) LRRK2 Gly2385Arg mutation and clinical features in a Chinese population with earlyonset Parkinson's disease compared to late-onset patients. $J$ Neural Transm, 115, 1275-1277.

[63] Choi JM, Woo MS, Ma H-I, Kang SY, Sung Y-H, Yong SW, Chung SJ, Kim J-S, Shin H, Lyoo CH, Lee PH, Baik JS, Kim S-J, Park MY, Sohn YH, Kim J-H, Kim JW, Lee MS, Lee MC, Kim D-H, \& Kim YJ (2008) Analysis of PARK genes in a Korean cohort of early-onset Parkinson disease. Neurogenetics, 9, 263-269.

[64] Zabetian CP, Yamamoto M, Lopez AN, Ujike H, Mata IF, Izumi Y, Kaji R, Maruyama H, Morino H, Oda M, Hutter CM, Edwards KL, Schellenberg GD, Tsuang DW, Yearout D, Larson EB, \& Kawakami H (2009) LRRK2 mutations and risk variants in Japanese patients with Parkinson's disease. Mov Disord, 24, 1034-1041.

[65] Kim J-M, Lee J-Y, Kim HJ, Kim JS, Shin E-S, Cho J-H, Park SS, \& Jeon BS (2010) The LRRK2 G2385R variant is a risk factor for sporadic Parkinson's disease in the Korean population. Parkinsonism Relat Disord, 16, 85-88.

[66] Tan E-K, Peng R, Teo Y-Y, Tan LC, Angeles D, Ho P, Chen M-L, Lin C-H, Mao X-Y, Chang X-L, Prakash KM, Liu J-J, Au W-L, Le W-D, Jankovic J, Burgunder J-M, Zhao Y, \& Wu R-M (2010) Multiple LRRK2 variants modulate risk of Parkinson disease: A Chinese multicenter study. Hum Mutat, 31, 561-568

[67] Miyake Y, Tsuboi Y, Koyanagi M, Fujimoto T, Shirasawa S, Kiyohara C, Tanaka K, Fukushima W, Sasaki S, Yamada T, Oeda T, Miki T, Kawamura N, Sakae N, Fukuyama H, Hirota Y, \& Nagai M (2010) LRRK2 Gly2385Arg polymorphism, cigarette smoking, and risk of sporadic Parkinson's disease: A case-control study in Japan. J Neurol Sci, 297, 15-18.

[68] Lin C-H, Wu R-M, Tai C-H, Chen M-L, \& Hu F-C (2011) Lrrk2 S1647T and BDNF V66M interact with environmental factors to increase risk of Parkinson's disease. Parkinsonism Relat Disord, 17, 84-88.

[69] Lill CM, Roehr JT, McQueen MB, Kavvoura FK, Bagade S, Schjeide B-MM, Schjeide LM, Meissner E, Zauft U, Allen NC, Liu T, Schilling M, Anderson KJ, Beecham G, Berg D, Biernacka JM, Brice A, Destefano AL, Do CB, Eriksson N, Factor SA, Farrer MJ, Foroud T, Gasser T, Hamza T, Hardy JA, Heutink P, Hill-Burns EM, Klein C, Latourelle JC, 
Maraganore DM, Martin ER, Martinez M, Myers RH, Nalls MA, Pankratz N, Payami H, Satake W, Scott WK, Sharma M, Singleton AB, Stefansson K, Toda T, Tung JY, Vance J, Wood NW, Zabetian CP, Young P, Tanzi RE, Khoury MJ, Zipp F, Lehrach H, Ioannidis JPA, \& Bertram L (2012) Comprehensive Research Synopsis and Systematic MetaAnalyses in Parkinson's Disease Genetics: The PDGene Database. PLoS Genetics, 8, e1002548.

[70] Ross OA, Wu Y-R, Lee M-C, Funayama M, Chen M-L, Soto AI, Mata IF, Lee-Chen G-J, Chen CM, Tang M, Zhao Y, Hattori N, Farrer MJ, Tan E-K, \& Wu R-M (2008) Analysis of Lrrk2 R1628P as a risk factor for Parkinson's disease. Ann Neurol, 64, 88-92.

[71] Tan E-K, Tang M, Tan LC, Wu Y-R, Wu R-M, Ross OA, \& Zhao Y (2008) Lrrk2 R1628P in non-Chinese Asian races. Ann Neurol, 64, 472-473.

[72] Lu C-S, Wu-Chou Y-H, van Doeselaar M, Simons EJ, Chang H-C, Breedveld GJ, Di Fonzo A, Chen R-S, Weng Y-H, Lai S-C, Oostra BA, \& Bonifati V (2008) The LRRK2 Arg 1628Pro variant is a risk factor for Parkinson's disease in the Chinese population. Neurogenetics, 9, 271-276.

[73] Zhang Z, Burgunder J-M, An X, Wu Y, Chen W, Zhang J, Wang Y, Xu Y, Gou Y, Yuan G, Mao X, \& Peng R (2009) LRRK2 R1628P variant is a risk factor of Parkinson's disease among Han-Chinese from mainland China. Mov Disord, 24, 1902-1905.

[74] Yu L, Hu F, Zou X, Jiang Y, Liu Y, He X, Xi J, Liu L, Liu Z, He L, \& Xu Y (2009) LRRK2 R1628P contributes to Parkinson's disease susceptibility in Chinese Han populations from mainland China. Brain Res, 1296, 113-116.

[75] Fu X, Zheng Y, Hong H, He Y, Zhou S, Guo C, Liu Y, Xian W, Zeng J, Li J, Liu Z, Chen L, \& Pei Z (2012) LRRK2 G2385R and LRRK2 R1628P increase risk of Parkinson's disease in a Han Chinese population from Southern Mainland China. Parkinsonism Relat Disord, 19, 397-398.

[76] Pulkes T, Papsing C, Mahasirimongkol S, Busabaratana M, Kulkantrakorn K, \& Tiamkao S (2011) Frequencies of LRRK2 variants in Thai patients with Parkinson's disease: Evidence for an R1628P founder. J Neurol Neurosurg Psychiatr, 82, 1179-1180.

[77] Paisán-Ruíz C, Nath P, Washecka N, Gibbs JR, \& Singleton AB (2008) Comprehensive analysis of LRRK2 in publicly available Parkinson's disease cases and neurologically normal controls. Hum Mutat, 29, 485-490.

[78] Nuytemans K, Meeus B, Crosiers D, Brouwers N, Goossens D, Engelborghs S, Pals P, Pickut B, Van den Broeck M, Corsmit E, Cras P, De Deyn PP, Del-Favero J, Van Broeckhoven C, \& Theuns J (2009) Relative contribution of simple mutations vs. copy number variations in five Parkinson disease genes in the Belgian population. Human Mutation, 30, 1054-1061.

[79] Chung SJ, Armasu SM, Biernacka JM, Lesnick TG, Rider DN, Lincoln SJ, Ortolaza AI, Farrer MJ, Cunningham JM, Rocca WA, \& Maraganore DM (2011) Common variants in PARK loci and related genes and Parkinson's disease. Movement Disorders, 26, 280-288.

[80] Li N-N, Tan E-K, Chang X-L, Mao X-Y, Zhang J-H, Zhao D-M, Liao Q, \& Peng R (2012) Genetic analysis of LRRK2 A419V variant in ethnic Chinese. Neurobiol Aging, 33, 1849.e1-3.

[81] Wu YR, Tan LC, Fu X, Chen CM, Au WL, Chen L, Chen YC, Prakash KM, Zheng Y, Lee-Chen G-J, Zhao Y, Zeng JS, Tan EK, \& Pei Z (2012) LRRK2 A419V is not associated with Parkinson's disease in different Chinese populations. PLoS ONE, 7, e36123.
[82] Wu X, Tang K-F, Li Y, Xiong Y-Y, Shen L, Wei Z-Y, Zhou K-J, Niu J-M, Han X, Yang L, Feng G-Y, He L, \& Qin S-Y (2012) Quantitative assessment of the effect of LRRK2 exonic variants on the risk of Parkinson's disease: A metaanalysis. Parkinsonism Relat Disord, 18, 722-730.

[83] Wu-Chou Y-H, Chen Y-T, Yeh T-H, Chang H-C, Weng Y-H, Lai S-C, Huang C-L, Chen R-S, Huang Y-Z, Chen C-C, Hung J, Chuang W-L, Lin W-Y, Chen C-H, \& Lu C-S (2012) Genetic variants of SNCA and LRRK2 genes are associated with sporadic PD susceptibility: A replication study in a Taiwanese cohort. Parkinsonism Relat Disord, 19, 251-255.

[84] Hindorff LA, Sethupathy P, Junkins HA, Ramos EM, Mehta JP, Collins FS, \& Manolio TA (2009) Potential etiologic and functional implications of genome-wide association loci for human diseases and traits. Proc Natl Acad Sci USA, 106, 9362-9367.

[85] Satake W, Nakabayashi Y, Mizuta I, Hirota Y, Ito C, Kubo M, Kawaguchi T, Tsunoda T, Watanabe M, Takeda A, Tomiyama H, Nakashima K, Hasegawa K, Obata F, Yoshikawa T, Kawakami H, Sakoda S, Yamamoto M, Hattori N, Murata M, Nakamura Y, \& Toda T (2009) Genome-wide association study identifies common variants at four loci as genetic risk factors for Parkinson's disease. Nat Genet, 41, 1303-1307.

[86] Nalls MA, Plagnol V, Hernandez DG, Sharma M, Sheerin U-M, Saad M, Simón-Sánchez J, Schulte C, Lesage S, Sveinbjörnsdóttir S, Stefánsson K, Martinez M, Hardy J, Heutink P, Brice A, Gasser T, Singleton AB, \& Wood NW (2011) Imputation of sequence variants for identification of genetic risks for Parkinson's disease: A meta-analysis of genome-wide association studies. Lancet, 377, 641-649.

[87] Sharma M, Ioannidis JPA, Aasly JO, Annesi G, Brice A, Van Broeckhoven C, Bertram L, Bozi M, Crosiers D, Clarke C, Facheris M, Farrer M, Garraux G, Gispert S, Auburger G, Vilariño-Güell C, Hadjigeorgiou GM, Hicks AA, Hattori N, Jeon B, Lesage S, Lill CM, Lin J-J, Lynch T, Lichtner P, Lang AE, Mok V, Jasinska-Myga B, Mellick GD, Morrison KE, Opala G, Pramstaller PP, Pichler I, Park SS, Quattrone A, Rogaeva E, Ross OA, Stefanis L, Stockton JD, Satake W, Silburn PA, Theuns J, Tan E-K, Toda T, Tomiyama H, Uitti RJ, Wirdefeldt K, Wszolek Z, Xiromerisiou G, Yueh K-C, Zhao Y, Gasser T, Maraganore D, \& Krüger R (2012) Large-scale replication and heterogeneity in Parkinson disease genetic loci. Neurology, 79, 659-667.

[88] Gibbs JR, van der Brug MP, Hernandez DG, Traynor BJ, Nalls MA, Lai S-L, Arepalli S, Dillman A, Rafferty IP, Troncoso J, Johnson R, Zielke HR, Ferrucci L, Longo DL, Cookson MR, \& Singleton AB (2010) Abundant Quantitative Trait Loci Exist for DNA Methylation and Gene Expression in Human Brain. PLoS Genet, 6, e1000952.

[89] Singleton A, \& Hardy J (2011) A generalizable hypothesis for the genetic architecture of disease: Pleomorphic risk loci. Human Molecular Genetics, 20, R158-R162.

[90] Jonsson T, Stefansson H, Steinberg S, Jonsdottir I, Jonsson PV, Snaedal J, Bjornsson S, Huttenlocher J, Levey AI, Lah JJ, Rujescu D, Hampel H, Giegling I, Andreassen OA, Engedal K, Ulstein I, Djurovic S, Ibrahim-Verbaas C, Hofman A, Ikram MA, van Duijn CM, Thorsteinsdottir U, Kong A, \& Stefansson K (2013) Variant of TREM2 associated with the risk of Alzheimer's disease. N Engl J Med, 368, 107-116.

[91] Guerreiro R, Wojtas A, Bras J, Carrasquillo M, Rogaeva E, Majounie E, Cruchaga C, Sassi C, Kauwe JSK, Younkin S, Hazrati L, Collinge J, Pocock J, Lashley T, Williams J, Lambert J-C, Amouyel P, Goate A, Rademakers R, Morgan 
K, Powell J, St George-Hyslop P, Singleton A, \& Hardy J (2013) TREM2 variants in Alzheimer's disease. $N$ Engl $J$ Med, 368, 117-127.

[92] Cookson MR (2010) The role of leucine-rich repeat kinase 2 (LRRK2) in Parkinson's disease. Nat Rev Neurosci, 11, 791-797.

[93] Bosgraaf L, \& Van Haastert PJ (2003) Roc, a Ras/GTPase domain in complex proteins. Biochim Biophys Acta, 1643, 5-10.

[94] Marin I (2006) The Parkinson disease gene LRRK2: Evolutionary and structural insights. Molecular Biology and Evolution, 23, 2423-2433.

[95] Lewis PA (2009) The function of ROCO proteins in health and disease. Biol Cell, 101, 183-191.

[96] Deng J, Lewis PA, Greggio E, Sluch E, Beilina A, \& Cookson MR (2008) Structure of the ROC domain from the Parkinson's disease-associated leucine-rich repeat kinase 2 reveals a dimeric GTPase. Proc Natl Acad Sci U S A, 105, 1499-1504.

[97] Gotthardt K, Weyand M, Kortholt A, Van Haastert PJ, \& Wittinghofer A (2008) Structure of the Roc-COR domain tandem of C. tepidum, a prokaryotic homologue of the human LRRK2 Parkinson kinase. EMBO J, 27, 2352.

[98] Gilsbach BK, Ho FY, Vetter IR, van Haastert PJ, Wittinghofer A, \& Kortholt A (2012) Roco kinase structures give insights into the mechanism of Parkinson diseaserelated leucine-rich-repeat kinase 2 mutations. Proc Natl Acad Sci U S A, 109, 10322-10327.

[99] Gasper R, Meyer S, Gotthardt K, Sirajuddin M, \& Wittinghofer A (2009) It takes two to tango: Regulation of G proteins by dimerization. Nat Rev Mol Cell Biol, 10, 423429.

[100] Greggio E, Zambrano I, Kaganovich A, Beilina A, Taymans JM, Daniels V, Lewis P, Jain S, Ding J, Syed A, Thomas KJ, Baekelandt V, \& Cookson MR (2008) The Parkinson disease-associated leucine-rich repeat kinase 2 (LRRK2) is a dimer that undergoes intramolecular autophosphorylation. J Biol Chem, 283, 16906-16914.

[101] Sen S, Webber PJ, \& West AB (2009) Dependence of leucine-rich repeat kinase 2 (LRRK2) kinase activity on dimerization. J Biol Chem, 284, 36346-36356.

[102] Klein CL, Rovelli G, Springer W, Schall C, Gasser T, \& Kahle PJ (2009) Homo- and heterodimerization of ROCO kinases: LRRK2 kinase inhibition by the LRRK2 ROCO fragment. J Neurochem, 111, 703-715.

[103] Ito G, \& Iwatsubo T (2012) Re-examination of the dimerization state of leucine-rich repeat kinase 2: Predominance of the monomeric form. Biochem J, 441, 987-994.

[104] civiero L, Vancraenenbroeck R, Belluzzi E, Beilina A, Lobbestael E, Reyniers L, Gao F, Micetic I, De Maeyer M, Bubacco L, Baekelandt V, Cookson MR, Greggio E, \& Taymans JM (2012) Biochemical characterization of highly purified leucine-rich repeat kinases 1 and 2 demonstrates formation of homodimers. PLoS One, 7, e43472.

[105] James NG, Digman MA, Gratton E, Barylko B, Ding X, Albanesi JP, Goldberg MS, \& Jameson DM (2012) Number and brightness analysis of LRRK2 oligomerization in live cells. Biophys J, 102, L41-L43.

[106] West AB, Moore DJ, Biskup S, Bugayenko A, Smith WW, Ross CA, Dawson VL, \& Dawson TM (2005) Parkinson's disease-associated mutations in leucine-rich repeat kinase 2 augment kinase activity. Proc Natl Acad Sci U S A, 102, 16842-16847.

[107] Gloeckner CJ, Kinkl N, Schumacher A, Braun RJ, O’Neill E, Meitinger T, Kolch W, Prokisch H, \& Ueffing M (2006)
The Parkinson disease causing LRRK2 mutation I2020T is associated with increased kinase activity. Human molecular genetics, 15, 223-232.

[108] Greggio E, Jain S, Kingsbury A, Bandopadhyay R, Lewis P, Kaganovich A, van der Brug MP, Beilina A, Blackinton J, Thomas KJ, Ahmad R, Miller DW, Kesavapany S, Singleton A, Lees A, Harvey RJ, Harvey K, Cookson MR (2006) Kinase activity is required for the toxic effects of mutant LRRK2/dardarin. Neurobiol Dis, 23, 329-341.

[109] Lewis PA, Greggio E, Beilina A, Jain S, Baker A, \& Cookson MR (2007) The R1441C mutation of LRRK2 disrupts GTP hydrolysis. Biochemical and biophysical research communications, 357, 668-671.

[110] Guo L, Gandhi PN, Wang W, Petersen RB, Wilson-Delfosse AL, \& Chen SG (2007) The Parkinson's disease-associated protein, leucine-rich repeat kinase 2 (LRRK2), is an authentic GTPase that stimulates kinase activity. Experimental cell research, 313, 3658-3670.

[111] Li X, Tan YC, Poulose S, Olanow CW, Huang XY, \& Yue Z (2007) Leucine-rich repeat kinase 2 (LRRK2)/PARK8 possesses GTPase activity that is altered in familial Parkinson's disease R1441C/G mutants. J Neurochem, 103, 238-247.

[112] Korr D, Toschi L, Donner P, Pohlenz HD, Kreft B, \& Weiss B (2006) LRRK1 protein kinase activity is stimulated upon binding of GTP to its Roc domain. Cell Signal, 18, 910-920.

[113] Ito G, Okai T, Fujino G, Takeda K, Ichijo H, Katada T, \& Iwatsubo T (2007) GTP Binding Is Essential to the Protein Kinase Activity of LRRK2, a Causative Gene Product for Familial Parkinson's Disease. Biochemistry, 46, 1380-1388.

[114] West AB, Moore DJ, Choi C, Andrabi SA, Li X, Dikeman D, Biskup S, Zhang Z, Lim KL, Dawson VL, \& Dawson TM (2007) Parkinson's disease-associated mutations in LRRK2 link enhanced GTP-binding and kinase activities to neuronal toxicity. Hum Mol Genet, 16, 223-232.

[115] Smith WW, Pei Z, Jiang H, Dawson VL, Dawson TM, \& Ross CA (2006) Kinase activity of mutant LRRK2 mediates neuronal toxicity. Nature neuroscience, 9, 1231-1233.

[116] Taymans JM, Vancraenenbroeck R, Ollikainen P, Beilina A, Lobbestael E, De Maeyer M, Baekelandt V, \& Cookson MR (2011) LRRK2 Kinase Activity Is Dependent on LRRK2 GTP Binding Capacity but Independent of LRRK2 GTP Binding. PLoS One, 6, e23207

[117] Greggio E, Taymans JM, Zhen EY, Ryder J, Vancraenenbroeck R, Beilina A, Sun P, Deng J, Jaffe H, Baekelandt V, Merchant K, \& Cookson MR (2009) The Parkinson's disease kinase LRRK2 autophosphorylates its GTPase domain at multiple sites. Biochem Biophys Res Commun, 389, 449454.

[118] Kamikawaji S, Ito G, \& Iwatsubo T (2009) Identification of the autophosphorylation sites of LRRK2. Biochemistry, $\mathbf{4 8}$, 10963-10975.

[119] Webber PJ, Smith AD, Sen S, Renfrow MB, Mobley JA, \& West AB (2011) Autophosphorylation in the Leucine-Rich Repeat Kinase 2 (LRRK2) GTPase Domain Modifies Kinase and GTP-Binding Activities. $J$ Mol Biol, 412, 94-110.

[120] Jaleel M, Nichols RJ, Deak M, Campbell DG, Gillardon F, Knebel A, \& Alessi DR (2007) LRRK2 phosphorylates moesin at threonine-558: Characterization of how Parkinson's disease mutants affect kinase activity. Biochem J, 405, 307-317.

[121] Rudenko IN, Kaganovich A, Hauser DN, Beylina A, Chia R, Ding J, Maric D, Jaffe H, \& Cookson MR (2012) The G2385R variant of leucine-rich repeat kinase 2 associated with Parkinson's disease is a partial loss-of-function mutation. Biochem J, 446, 99-111. 
[122] Berger Z, Smith KA, \& Lavoie MJ (2010) Membrane localization of LRRK2 is associated with increased formation of the highly active LRRK2 dimer and changes in its phosphorylation. Biochemistry, 49, 5511-5523.

[123] Lewis PA, \& Manzoni C (2012) LRRK2 and human disease: A complicated question or a question of complexes? $\mathrm{Sci}$ Signal, 5, pe2.

[124] Berwick DC, \& Harvey K (2011) LRRK2 signaling pathways: The key to unlocking neurodegeneration? Trends Cell Biol, 21, 257-265.

[125] Imai Y, Gehrke S, Wang HQ, Takahashi R, Hasegawa K, Oota E, \& Lu B (2008) Phosphorylation of 4E-BP by LRRK2 affects the maintenance of dopaminergic neurons in Drosophila. Embo J, 27, 2432-2443.

[126] Dzamko N, Inesta-Vaquera F, Zhang J, Xie C, Cai H, Arthur S, Tan L, Choi H, Gray N, Cohen P, Pedrioli P, Clark K, \& Alessi DR (2012) The IkappaB Kinase Family Phosphorylates the Parkinson's Disease Kinase LRRK2 at Ser935 and Ser910 during Toll-Like Receptor Signaling. PLoS One, 7, e39132.

[127] Sancho RM, Law BM, \& Harvey K (2009) Mutations in the LRRK2 Roc-COR tandem domain link Parkinson's disease to Wnt signalling pathways. Hum Mol Genet, 18, 39553968

[128] Bravo-San Pedro JM, Niso-Santano M, Gomez-Sanchez R, Pizarro-Estrella E, Aiastui-Pujana A, Gorostidi A, Climent V, Lopez de Maturana R, Sanchez-Pernaute R, Lopez de Munain A, Fuentes JM, \& Gonzalez-Polo RA (2012) The LRRK2 G2019S mutant exacerbates basal autophagy through activation of the MEK/ERK pathway. Cell Mol Life Sci, 70, 121-136.

[129] Nichols RJ, Dzamko N, Morrice NA, Campbell DG, Deak M, Ordureau A, Macartney T, Tong Y, Shen J, Prescott AR, \& Alessi DR (2010) 14-3-3 binding to LRRK2 is disrupted by multiple Parkinson's disease-associated mutations and regulates cytoplasmic localization. Biochem J, 430, 393404.

[130] Li X, Wang QJ, Pan N, Lee S, Zhao Y, Chait BT, \& Yue Z (2011) Phosphorylation-dependent 14-3-3 binding to LRRK2 is impaired by common mutations of familial Parkinson's disease. PLoS One, 6, e17153.

[131] Dzamko N, Deak M, Hentati F, Reith AD, Prescott AR, Alessi DR, \& Nichols RJ (2010) Inhibition of LRRK2 kinase activity leads to dephosphorylation of $\operatorname{Ser}(910) / \operatorname{Ser}(935)$, disruption of 14-3-3 binding and altered cytoplasmic localization. Biochem J, 430, 405-413.

[132] Biskup S, Moore DJ, Celsi F, Higashi S, West AB, Andrabi SA, Kurkinen K, Yu S-W, Savitt JM, Waldvogel HJ, Faull RLM, Emson PC, Torp R, Ottersen OP, Dawson TM, \& Dawson VL (2006) Localization of LRRK2 to membranous and vesicular structures in mammalian brain. Ann Neurol, 60, 557-569.

[133] Hatano T, Kubo S-I, Imai S, Maeda M, Ishikawa K, Mizuno Y, \& Hattori N (2007) Leucine-rich repeat kinase 2 associates with lipid rafts. Hum Mol Genet, 16, 678690.

[134] Alegre-Abarrategui J, Christian H, Lufino MMP, Mutihac R, Venda LL, Ansorge O, \& Wade-Martins R (2009) LRRK2 regulates autophagic activity and localizes to specific membrane microdomains in a novel human genomic reporter cellular model. Hum Mol Genet, 18, 4022-4034.

[135] Piccoli G, Condliffe SB, Bauer M, Giesert F, Boldt K, De Astis S, Meixner A, Sarioglu H, Vogt-Weisenhorn DM, Wurst W, Gloeckner CJ, Matteoli M, Sala C, \& Ueffing M (2011) LRRK2 controls synaptic vesicle storage and mobilization within the recycling pool. J Neurosci, 31, 22252237.

[136] Matta S, Van Kolen K, da Cunha R, van den Bogaart G, Mandemakers W, Miskiewicz K, De Bock P-J, Morais VA, Vilain S, Haddad D, Delbroek L, Swerts J, Chávez-Gutiérrez L, Esposito G, Daneels G, Karran E, Holt M, Gevaert K, Moechars DW, De Strooper B, \& Verstreken P (2012) LRRK2 controls an EndoA phosphorylation cycle in synaptic endocytosis. Neuron, 75, 1008-1021.

[137] Alegre-Abarrategui J, Ansorge O, Esiri M, \& Wade-Martins $\mathrm{R}$ (2008) LRRK2 is a component of granular alphasynuclein pathology in the brainstem of Parkinson's disease. Neuropathol Appl Neurobiol, 34, 272-283.

[138] Gómez-Suaga P, Luzón-Toro B, Churamani D, Zhang L, Bloor-Young D, Patel S, Woodman PG, Churchill GC, \& Hilfiker S (2012) Leucine-rich repeat kinase 2 regulates autophagy through a calcium-dependent pathway involving NAADP. Hum Mol Genet, 21, 511-525.

[139] Sánchez-Danés A, Richaud-Patin Y, Carballo-Carbajal I, Jiménez-Delgado S, Caig C, Mora S, Di Guglielmo C, Ezquerra M, Patel B, Giralt A, Canals JM, Memo M, Alberch J, López-Barneo J, Vila M, Cuervo AM, Tolosa E, Consiglio A, \& Raya A (2012) Disease-specific phenotypes in dopamine neurons from human iPS-based models of genetic and sporadic Parkinson's disease. EMBO Mol Med, 4, 380395.

[140] Tong Y, Yamaguchi H, Giaime E, Boyle S, Kopan R, Kelleher RJ 3rd, \& Shen J (2010) Loss of leucine-rich repeat kinase 2 causes impairment of protein degradation pathways, accumulation of alpha-synuclein, and apoptotic cell death in aged mice. Proc Natl Acad Sci USA, 107, 98799884.

[141] Herzig MC, Kolly C, Persohn E, Theil D, Schweizer T, Hafner T, Stemmelen C, Troxler TJ, Schmid P, Danner S, Schnell CR, Mueller M, Kinzel B, Grevot A, Bolognani F, Stirn M, Kuhn RR, Kaupmann K, van der Putten PH, Rovelli G, \& Shimshek DR (2011) LRRK2 protein levels are determined by kinase function and are crucial for kidney and lung homeostasis in mice. Hum Mol Genet, 20, 42094223.

[142] Orenstein SJ, Kuo S-H, Tasset I, Arias E, Koga H, Fernandez-Carasa I, Cortes E, Honig LS, Dauer W, Consiglio A, Raya A, Sulzer D, \& Cuervo AM (2013) Interplay of LRRK2 with chaperone-mediated autophagy. Nat Neurosci, 16, 394-406.

[143] Macleod DA, Rhinn H, Kuwahara T, Zolin A, Di Paolo G, Maccabe BD, Marder KS, Honig LS, Clark LN, Small SA, \& Abeliovich A (2013) RAB7L1 Interacts with LRRK2 to Modify Intraneuronal Protein Sorting and Parkinson's Disease Risk. Neuron, 77, 425-439.

[144] Gehrke S, Imai Y, Sokol N, \& Lu B (2010) Pathogenic LRRK2 negatively regulates microRNA-mediated translational repression. Nature, 466, 637-41.

[145] Cho HJ, Liu G, Jin SM, Parisiadou L, Xie C, Yu J, Sun L, Ma B, Ding J, Vancraenenbroeck R, Lobbestael E, Baekelandt V, Taymans J-M, He P, Troncoso JC, Shen Y, Cai H (2013) MicroRNA-205 regulates the expression of Parkinson's disease-related leucine-rich repeat kinase 2 protein. Hum Mol Genet, 22, 608-620.

[146] Gandhi PN, Wang X, Zhu X, Chen SG, \& Wilson-Delfosse AL (2008) The Roc domain of leucine-rich repeat kinase 2 is sufficient for interaction with microtubules. J Neurosci Res, 86, 1711-1720.

[147] Gillardon F (2009) Leucine-rich repeat kinase 2 phosphorylates brain tubulin-beta isoforms and modulates microtubule 
stability-a point of convergence in parkinsonian neurodegeneration? J Neurochem, 110, 1514-1522.

[148] Meixner A, Boldt K, Van Troys M, Askenazi M, Gloeckner CJ, Bauer M, Marto JA, Ampe C, Kinkl N, \& Ueffing M (2011) A QUICK screen for Lrrk2 interaction partnersleucine-rich repeat kinase 2 is involved in actin cytoskeleton dynamics. Mol Cell Proteomics, 10, M110.001172.

[149] Chan D, Citro A, Cordy JM, Shen GC, \& Wolozin B (2011) Rac1 protein rescues neurite retraction caused by G2019S leucine-rich repeat kinase 2 (LRRK2). J Biol Chem, 286, 16140-16149.

[150] Parisiadou L, Xie C, Cho HJ, Lin X, Gu X-L, Long C-X, Lobbestael E, Baekelandt V, Taymans J-M, Sun L, \& Cai H (2009) Phosphorylation of ezrin/radixin/moesin proteins by LRRK2 promotes the rearrangement of actin cytoskeleton in neuronal morphogenesis. J Neurosci, 29, 13971-13980.

[151] Gardet A, Benita Y, Li C, Sands BE, Ballester I, Stevens C, Korzenik JR, Rioux JD, Daly MJ, Xavier RJ, \& Podolsky DK (2010) LRRK2 is involved in the IFN-gamma response and host response to pathogens. J Immunol, 185, 5577-5585.

[152] Hakimi M, Selvanantham T, Swinton E, Padmore RF, Tong Y, Kabbach G, Venderova K, Girardin SE, Bulman DE, Scherzer CR, LaVoie MJ, Gris D, Park DS, Angel JB, Shen J, Philpott DJ, \& Schlossmacher MG (2011) Parkinson's disease-linked LRRK2 is expressed in circulating and tissue immune cells and upregulated following recognition of microbial structures. J Neural Transm 118, 795-808.

[153] Zhang F-R, Huang W, Chen S-M, Sun L-D, Liu H, Li Y, Cui Y, Yan X-X, Yang H-T, Yang R-D, Chu T-S, Zhang C, Zhang L, Han J-W, Yu G-Q, Quan C, Yu Y-X, Zhang Z, Shi B-Q, Zhang L-H, Cheng H, Wang C-Y, Lin Y, Zheng H-F, Fu X-A, Zuo X-B, Wang Q, Long H, Sun Y-P, Cheng Y-L, Tian H-Q, Zhou F-S, Liu H-X, Lu W-S, He S-M, Du W-L, Shen M, Jin Q-Y, Wang Y, Low H-Q, Erwin T, Yang N-H, Li J-Y, Zhao X, Jiao Y-L, Mao L-G, Yin G, Jiang Z-X, Wang X-D, Yu J-P, Hu Z-H, Gong C-H, Liu Y-Q, Liu R-Y, Wang D-M, Wei D, Liu J-X, Cao W-K, Cao H-Z, Li Y-P, Yan WG, Wei S-Y, Wang K-J, Hibberd ML, Yang S, Zhang X-J, \& Liu J-J (2009) Genomewide association study of leprosy. $N$ Engl J Med, 361, 2609-2618.

[154] Franke A, McGovern DPB, Barrett JC, Wang K, RadfordSmith GL, Ahmad T, Lees CW, Balschun T, Lee J, Roberts $\mathrm{R}$, Anderson CA, Bis JC, Bumpstead S, Ellinghaus D, Festen EM, Georges M, Green T, Haritunians T, Jostins L, Latiano A, Mathew CG, Montgomery GW, Prescott NJ, Raychaudhuri S, Rotter JI, Schumm P, Sharma Y, Simms LA, Taylor KD, Whiteman D, Wijmenga C, Baldassano RN, Barclay M, Bayless TM, Brand S, Büning C, Cohen A, Colombel J-F, Cottone M, Stronati L, Denson T, De Vos M, D'Inca R, Dubinsky M, Edwards C, Florin T, Franchimont D, Gearry R, Glas J, Van Gossum A, Guthery SL, Halfvarson J, Verspaget HW, Hugot J-P, Karban A, Laukens D, Lawrance I, Lemann M, Levine A, Libioulle C, Louis E, Mowat C, Newman W, Panés J, Phillips A, Proctor DD, Regueiro M, Russell R, Rutgeerts P, Sanderson J, Sans M, Seibold F, Steinhart AH, Stokkers PCF, Torkvist L, KullakUblick G, Wilson D, Walters T, Targan SR, Brant SR, Rioux JD, D'Amato M, Weersma RK, Kugathasan S, Griffiths AM, Mansfield JC, Vermeire S, Duerr RH, Silverberg MS, Satsangi J, Schreiber S, Cho JH, Annese V, Hakonarson H, Daly MJ, \& Parkes M (2010) Genome-wide meta-analysis increases to 71 the number of confirmed Crohn's disease susceptibility loci. Nat Genet, 42, 1118-1125.

[155] Moehle MS, Webber PJ, Tse T, Sukar N, Standaert DG, DeSilva TM, Cowell RM, \& West AB (2012) LRRK2 inhibition attenuates microglial inflammatory responses. J Neurosci, 32, 1602-1611.

[156] Marker DF, Puccini JM, Mockus TE, Barbieri J, Lu S-M, \& Gelbard HA (2012) LRRK2 kinase inhibition prevents pathological microglial phagocytosis in response to HIV-1 Tat protein. J Neuroinflammation, 9, 261.

[157] Liu M, Kang S, Ray S, Jackson J, Zaitsev AD, Gerber SA, Cuny GD, \& Glicksman MA (2011) Kinetic, mechanistic, and structural modeling studies of truncated wild-type leucine-rich repeat kinase 2 and the G2019S mutant. Biochemistry, 50, 9399-9408.

[158] Greggio E, \& Cookson MR (2009) Leucine Rich Repeat Kinase 2 mutations and Parkinson's disease: Three Questions. ASN Neuro, 1, e00002.

[159] Li Y, Dunn L, Greggio E, Krumm B, Jackson GS, Cookson MR, Lewis PA, \& Deng J (2009) The R1441C mutation alters the folding properties of the ROC domain of LRRK2. Biochim Biophys Acta, 1792, 1194-1197.

[160] Ohta E, Katayama Y, Kawakami F, Yamamoto M, Tajima K, Maekawa T, Iida N, Hattori S, \& Obata F (2009) I(2020)T leucine-rich repeat kinase 2, the causative mutant molecule of familial Parkinson's disease, has a higher intracellular degradation rate than the wild-type molecule. Biochem Biophys Res Commun, 390, 710-715.

[161] Ho CC, Rideout HJ, Ribe E, Troy CM, \& Dauer WT (2009) The Parkinson disease protein leucine-rich repeat kinase 2 transduces death signals via Fas-associated protein with death domain and caspase- 8 in a cellular model of neurodegeneration. J Neurosci, 29, 1011-1016.

[162] Ren G, Xin S, Li S, Zhong H, \& Lin S (2011) Disruption of LRRK2 does not cause specific loss of dopaminergic neurons in zebrafish. PLOS ONE 6, e20630.

[163] Sheng D, Qu D, Kwok KHH, Ng SS, Lim AYM, Aw SS, Lee CWH, Sung WK, Tan EK, Lufkin T, Jesuthasan S, Sinnakaruppan M, \& Liu J (2010) Deletion of the WD40 domain of LRRK2 in Zebrafish causes Parkinsonism-like loss of neurons and locomotive defect. PLoS Genet, 6, e1000914

[164] Yao C, Johnson WM, Gao Y, Wang W, Zhang J, Deak M, Alessi DR, Zhu X, Mieyal JJ, Roder H, Wilson-Delfosse AL, \& Chen SG (2013) Kinase inhibitors arrest neurodegeneration in cell and C. elegans models of LRRK2 toxicity. Hum Mol Genet, 22, 328-344.

[165] Yuan Y, Cao P, Smith MA, Kramp K, Huang Y, Hisamoto N, Matsumoto K, Hatzoglou M, Jin H, \& Feng Z (2011) Dysregulated LRRK2 signaling in response to endoplasmic reticulum stress leads to dopaminergic neuron degeneration in C. elegans. PLoS ONE, 6, e22354.

[166] Sakaguchi-Nakashima A, Meir JY, Jin Y, Matsumoto K, \& Hisamoto N (2007) LRK-1, a C. elegans PARK8-related kinase, regulates axonal-dendritic polarity of SV proteins. Curr Biol, 17, 592-598.

[167] Lee SB, Kim W, Lee S, \& Chung J (2007) Loss of LRRK2/PARK8 induces degeneration of dopaminergic neurons in Drosophila. Biochem Biophys Res Commun, 358, 534-539.

[168] Liu Z, Wang X, Yu Y, Li X, Wang T, Jiang H, Ren Q, Jiao Y, Sawa A, Moran T, Ross CA, Montell C, \& Smith WW (2008) A Drosophila model for LRRK2-linked parkinsonism. Proc Natl Acad Sci USA, 105, 2693-2698.

[169] Marín I (2008) Ancient origin of the Parkinson disease gene LRRK2. J Mol Evol, 67, 41-50.

[170] Xu Q, Shenoy S, \& Li C (2012) Mouse models for LRRK2 Parkinson's disease. Parkinsonism Relat Disord, 18(Suppl 1), S186-S189. 
[171] Beal MF (2010) Parkinson's disease: A model dilemma. Nature, 466, S8-S10.

[172] Li Y, Liu W, Oo TF, Wang L, Tang Y, Jackson-Lewis V, Zhou C, Geghman K, Bogdanov M, Przedborski S, Beal MF, Burke RE, \& Li C (2009) Mutant LRRK2(R1441G) BAC transgenic mice recapitulate cardinal features of Parkinson's disease. Nat Neurosci, 12, 826-828.

[173] Lin X, Parisiadou L, Gu X-L, Wang L, Shim H, Sun L, Xie C, Long C-X, Yang W-J, Ding J, Chen ZZ, Gallant PE, Tao-Cheng J-H, Rudow G, Troncoso JC, Liu Z, Li Z, \& Cai H (2009) Leucine-rich repeat kinase 2 regulates the progression of neuropathology induced by Parkinson's-disease-related mutant alpha-synuclein. $\mathrm{Neu}$ ron, 64, 807-827.

[174] Melrose HL, Dächsel JC, Behrouz B, Lincoln SJ, Yue M, Hinkle KM, Kent CB, Korvatska E, Taylor JP, Witten L, Liang Y-Q, Beevers JE, Boules M, Dugger BN, Serna VA, Gaukhman A, Yu X, Castanedes-Casey M, Braithwaite AT, Ogholikhan S, Yu N, Bass D, Tyndall G, Schellenberg GD, Dickson DW, Janus C, \& Farrer MJ (2010) Impaired dopaminergic neurotransmission and microtubule-associated protein tau alterations in human LRRK2 transgenic mice. Neurobiol Dis, 40, 503-517.

[175] MacLeod D, Dowman J, Hammond R, Leete T, Inoue K, \& Abeliovich A (2006) The familial Parkinsonism gene
LRRK2 regulates neurite process morphology. Neuron, 52, 587-593.

[176] Tong Y, Pisani A, Martella G, Karouani M, Yamaguchi H, Pothos EN, \& Shen J (2009) R1441C mutation in LRRK2 impairs dopaminergic neurotransmission in mice. Proc Natl Acad Sci USA, 106, 14622-14627.

[177] Lee BD, Shin J-H, VanKampen J, Petrucelli L, West AB, Ko HS, Lee Y-I, Maguire-Zeiss KA, Bowers WJ, Federoff HJ, Dawson VL, \& Dawson TM (2010) Inhibitors of leucinerich repeat kinase-2 protect against models of Parkinson's disease. Nat Med, 16, 998-1000.

[178] Dusonchet J, Kochubey O, Stafa K, Young SM Jr, Zufferey R, Moore DJ, Schneider BL, \& Aebischer P (2011) A rat model of progressive nigral neurodegeneration induced by the Parkinson's disease-associated G2019S mutation in LRRK2. J Neurosci, 31, 907-912.

[179] Liu Z, Lee J, Krummey S, Lu W, Cai H, \& Lenardo MJ (2011) The kinase LRRK2 is a regulator of the transcription factor NFAT that modulates the severity of inflammatory bowel disease. Nat Immunol, 12, 1063-1070.

[180] Deng X, Dzamko N, Prescott A, Davies P, Liu Q, Yang Q, Lee JD, Patricelli MP, Nomanbhoy TK, Alessi DR, \& Gray NS (2011) Characterization of a selective inhibitor of the Parkinson's disease kinase LRRK2. Nat Chem Biol, 7, 203-205. 